\title{
ENCUESTA \\ SOBRE LA REFORMA DE LA LEY ORGÁNICA DEL TRIBUNAL CONSTITUCIONAL
}

La importancia que en nuestro Derecho político vigente ha de reconocerse a la Ley Orgánica del Tribunal Constitucional, ha estado siempre al margen de cualquier discusión.

Estamos en presencia de la única Ley orgánica de desarrollo de nuestra Lex normarum cuyo borrador se confeccionó en la cocina del Ministerio de Justicia (bajo la atenta batuta de Landelino Lavilla) al mismo tiempo que se mantenían en las Cámaras los debates constituyentes. Aquel texto, esmeradamente pulido, fue puesto sobre la mesa del Consejo de Ministros en la primera sesión que el mismo celebró tras las elecciones generales de marzo de 1979, aprobado y remitido como Proyecto al Congreso de los Diputados. Esta prioridad temporal — bien pudiera calificarse de superlativa urgencia - era claro reflejo de la idea indiscutida en la época de que los derechos y libertades que consagraba la Constitución debían gozar de las más elevadas garantías - ya sabemos que el mismo criterio condujo a redactar, debatir y aprobar a la vez que la Constitución la Ley 62/1978 de Protección Jurisdiccional de los Derechos fundamentales de las personascomo de la preocupación por la necesidad de dotar de interpretación suprema a un Título VIII de la Constitución tan abierto como importante. Y, por supuesto, lo significativo de las restantes competencias del Tribunal Constitucional era algo asumido por los diversos partidos políticos.

De todos es sabido que la LOTC de 3 de octubre de 1979 siempre gozó de un juicio favorable en nuestra doctrina y que nadie ha propuesto nunca que fuera objeto de reforma de nueva planta. Sin embargo el paso de su elaboración en "probeta de laboratorio", por mucho que se tuvieran presentes experiencias de Tribunales Constitucionales de la Europa de la postguerra, a su vigencia práctica, pronto puso de manifiesto la necesidad de ajustes y adaptaciones requeridos por las lecciones de la práctica cotidiana. De hecho esta Ley orgánica ha conocido de cinco reformas anteriores a la que se encuentra debatiéndose en el Congreso cuando hemos formulado nuestras preguntas y obtenido las respuestas que nos honramos en publicar. Pero la reforma que ahora nos ocupa es sensiblemente más ambiciosa que las anteriores y quizás puede decirse que es una revisión no puntual sino general. 
En efecto, su propia exposición de motivos confiesa que se procura "afrontar de manera conjunta las dificultades de funcionamiento del Tribunal Constitucional". Tales dificultades habían sido expuestas al Ministerio de Justicia por los Magistrados que actualmente componen el Tribunal Constitucional y por sus predecesores, de manera que creemos puede decirse que la reforma lejos de ser hija de planteamientos dogmáticos de cátedra es producto de las dificultades con que a diario ha tropezado el alto Tribunal en sus quehaceres. Y como esa problemática iba in crecendo la exigencia de abordar la subsiguiente reforma se ha elevado con voz progresivamente más fuerte, que finalmente ha sido escuchada por el Gobierno y producido el Proyecto de ley que es el sustrato de la encuesta que presentamos a nuestros lectores.

Como la amplitud de la reforma de la LOTC es compatible con que la mayor parte de la misma se centre en la reestructuración del recurso de amparo, nos ha parecido obligado dedicar buena parte de nuestras preguntas a esta temática. Mientras que al resto de las cuestiones dedicamos otras preguntas.

La totalidad de los catedráticos encuestados habían dedicado ya aportaciones relevantes a las competencias de nuestro intérprete supremo de la Constitución e incluso específicamente a su saturación por la avalancha de recursos de amparo que casi lo sepultan. A ellos hemos pedido su valiosa opinión, con nuestro ruego habitual de que la expusiesen con la mayor libertad. Desde aquí les reiteramos nuestro más sincero agradecimiento.

\section{PREgUnTAS}

1. ¿La aspiración ya tradicional de la mayoría de los Magistrados del Tribunal Constitucional de tramitar un menor número de recursos de amparo le parece plenamente justificada o cree que encierra algún peligro de reducir la protección práctica de los derechos y libertades fundamentales?

2. ¿En qué medida la reforma de la jurisdicción ordinaria y, más en concreto, del incidente de nulidad de actuaciones pueden reducir el número de recursos de amparos ante el Tribunal Constitucional?

3. ¿Las modificaciones que introduce el Proyecto de reforma de la LOTC a su juicio contienen los requisitos y procedimientos idóneos para la pretendida reducción del número de recursos de amparo a tramitar?

4. ¿Qué otras fórmulas alternativas o complementarias, en su criterio, podrían tomarse en consideración para reformar el actual recurso de amparo?

5. ¿Qué opinión le merece que se considere la posibilidad de que se personen ante el Tribunal Constitucional las partes del proceso a quo en la cuestión de inconstitucionalidad?

6. ¿Está conforme con la regulación propuesta de los efectos temporales de las sentencias de inconstitucionalidad?

7. Por último ¿Cómo ve la posibilidad de atribuir a las Salas competencias hasta abora reservadas al Pleno, por ejemplo, en la resolución de recursos y cuestiones de inconstitucionalidad o de conflictos de competencias? 


\section{ENCUESTADOS}

Marc Carrillo, Catedrático de Derecho Constitucional de la Universidad Pompeu Fabra

Luis María Díez Picazo, Catedrático de Derecho Constitucional de la Universidad de Castilla La Mancha

Francisco Javier García Roca, Catedrático de Derecho Constitucional de la Universidad de Valladolid

Ángel Garrorena Morales, Catedrático de Derecho Constitucional de la Universidad de Murcia

Jesús González Pérez, Catedrático Emérito de Derecho Administrativo de la Universidad Complutense de Madrid

Pablo Lucas Murillo de la Cueva, Catedrático de Derecho Constitucional de la Universidad de Córdoba

\section{SOBRE LA REDUCCIÓN DEL NÚMERO DE RECURSOS DE AMPARO}

1. ¿La aspiración ya tradicional de la mayoría de los Magistrados del Tribunal Constitucional de tramitar un menor número de recursos de amparo le parece plenamente justificada o cree que encierra algún peligro de reducir la protección práctica de los derechos y libertades fundamentales?

\section{MARC CARRILLO}

No es cuestión de entrar a abordar los aspectos subjetivos de esta aspiración de los magistrados del Tribunal Constitucional. Lo que resulta relevante es que la constatación de que la jurisdicción constitucional se encuentra en una situación compleja porque no está en disposición de cumplir con las funciones constitucionales que le están atribuidas, es una percepción que desde hace ya demasiados años comparten no sólo una buena parte de los magistrados que lo han integrado y de los que en la actualidad lo componen, sino también de representantes de las diversas profesiones jurídicas. En este sentido cabe destacar que en el ámbito académico, la doctrina ius publicista, y en especial, un sector significado de los profesores de Derecho Constitucional, en una línea similar a la que mostraban sus homólogos alemanes respecto de los peligros que acechaban al Tribunal de Karlsruhe, ha puesto de manifiesto el peligro de colapso del Tribunal Constitucional a causa de una errónea concepción del recurso de amparo. Un recurso éste, entendido más como una instancia procesal del procedimiento de tutela de los derechos fundamentales, que no como una garantía extraordinaria para su protección, cuando se ha producido una lesión de bienes jurídicos dotados de contenido constitucional, y que sólo en razón de éste previo requisito deban ser tutelados, a través de un procedimiento especial y extraordinario como en puridad ha de ser entendida la demanda de amparo ante el Tribunal. 
El problema estructural de la acumulación de recursos de amparo ante el Tribunal Constitucional ha radicado en que la jurisdicción ordinaria, por razones de orden diverso, desde la entrada en vigor de la Constitución, no ha operado con todo el alcance que era preciso, como la sede natural o el ámbito habitual de tutela de los derechos fundamentales, que es la consecuencia directa que de la Constitución cabía derivar. Las razones son diversas, pero sin duda que tuvieron mucho que ver con las condiciones estructurales y también de orden subjetivo que presidieron, en el ámbito del Poder Judicial, la transición de la dictadura a la democracia. Una transición en la que, de hecho, el único elemento democrático en el panorama institucional eran las Cortes Generales elegidas el 15 de junio de 1977 y la propia Constitución de 1978 surgida de este primer Parlamento democrático, tras los cuarenta años de dictadura. El resto eran instancias de poder surgidas del régimen franquista. A este respecto, en los inicios del sistema democrático, los jueces y magistrados integrantes del Poder Judicial, eran en muchos casos orgullosos depositarios y, en todo caso, herederos de una cultura jurídica impermeable a valores y principios democráticos y a unas normas de cultura política muy distantes, cuando no claramente beligerantes, frente al principio de la división de poderes y la garantía de los derechos fundamentales de sus conciudadanos.

Estas circunstancias probablemente pueden explicar la opción del constituyente de recuperar la garantía especial que ya había existido durante la II República del recurso de amparo, residenciable ante una jurisdicción especial, como expresión de una cierta desconfianza ante el juez ordinario como único baluarte para la garantía de los derechos y libertades. Y ciertamente, razones para esta reticencia no eran infundadas como así puso de manifiesto aquel Auto 35/1980, nada menos que del Tribunal Supremo, en el que respecto del principio de igualdad y el derecho a no ser discriminado del artículo 14 CE se llegaba a sostener que no era otra cosa que "(...) un principio programático $y$ como tal su normativa y su ámbito se desenvuelven a través de leyes procedentes que le dan aplicación práctica. Sin olvidar, en relación a este mismo derecho, la Sentencia también del Tribunal Supremo de 8 de abril de 1982, referida a la filiación de un hijo natural, en la que el TS, respecto del citado artículo 14 CE afirmaba que el antiguo artículo 137 del Código Civil, no puede estimarse que haya devenido inconstitucional, "(...) porque el artículo 14 de la vigente Constitución establezca la igualdad de los españoles ante la ley, sin que pueda prevalecer discriminación alguna por razón de nacimiento, pues tal mandato tiene el alcance una declaración de principio...".

En este contexto, la jurisprudencia del Tribunal Constitucional en materia de derechos y libertades sentó desde el principio nuevos criterios interpretativos que, en la medida que vinculaban a la jurisdicción ordinaria (artículos 9.1 CE y 5.1 de la LOPJ), adoptó también un marcado carácter pedagógico para el conjunto de los operadores jurídicos, en especial los jueces y tribunales de la jurisdicción ordinaria. Y, desde luego, también para los abogados y los recurrentes. Pero con el transcurso del tiempo, el precio derivado de esta circunstancia ha sido, de facto, una reconversión del amparo constitucional en una última 
instancia judicial que ha conducido a una situación insostenible: así, si en 1980, cuando el Tribunal Constitucional inició su andadura se presentaron 218 recursos de amparo, diez años después, en 1990, se presentaron 2.896; en el año 2000 se llegó a 6.762 mientras que en 2005 la cifra llegó a 9.476. Una análisis más específico de esta dinámica estadística reflejada por la Memoria de 2005 del Tribunal, permite subrayar que - por ejemplo- en 2004, del total de 7.951 asuntos ingresados, 7.841 eran recursos de amparo. Ello significa que nada menos que el $98 \%$ de lo asuntos ingresados en un año en el Tribunal son amparos, que hacen que su función jurisdiccional quede en buena parte absorbida por la necesidad de resolver estas demandas de los ciudadanos ${ }^{1}$.

A estos problemas estructurales también se han añadido otros de naturaleza institucional, que han enfrentado al Tribunal Constitucional con el Tribunal Supremo. No han sido numerosos, pero en algunas ocasiones se han llegado a manifestar con una cierta truculencia. Bien, como consecuencia de la anulación de una sentencia del TS, como en los casos de investigación de la paternidad (STC 7/1994) o en el Preysler (STC 186/2001) o bien, sobre todo, con motivo de un supuesto de responsabilidad civil de los magistrados del Tribunal Constitucional, en la insólita y desafortunada Sentencia de la Sala $1 .{ }^{a}$ del Tribunal Supremo de 23 de enero de 2004. Frente a ambos supuestos de una hipotética guerra de corti, siguiendo el símil italiano, la reforma de la LOTC pretende reforzar al posición institucional de los magistrados y del Tribunal como órgano, y de reformular el recurso de amparo, intentando objetivar los motivos que han de permitir la admisión a trámite de un recurso.

Pues bien, con estos antecedentes la reforma del recurso de amparo contenida en el Proyecto de Ley Orgánica de reforma de la LOTC, en el marco de una revisión general de la jurisdicción constitucional, tendente a reducir o aligerar la carga de asuntos de amparo constitucional, no puede ser entendida como un peligro de reducir la protección práctica de los derechos y libertades fundamentales. La lógica de la reforma se centra en la objetivación del objeto del recurso, en el establecimiento de un criterio formulado en positivo para juzgar la admisión de los recursos y en el reforzamiento de la jurisdicción ordinaria a través de una nueva concepción del incidente de nulidad a de actuaciones.

Esta objetivación del recurso de amparo es una opción legítima del legislador. El artículo 53.2 de la la Constitución no prefigura un modelo explícito de recurso de amparo, si por ello se entiende que esta garantía especial de los derechos fundamentales excluye una concepción que refuerce el contenido objetivo. Lo que se ha consolidado en la práctica ha sido la condición subsidiaria del recurso de amparo ordinario. Por tanto, no hay una razón sólida por la que el peligro de reducir la protección práctica de los derechos y libertades tenga que producirse.

1 Tomo estas cifras del trabajo de FOSSAS ESPADALER, E., "El Projecte de reforma de la Llei Orgánica del Tribunal Constitucional». El Clip. Institut d'Estudis Autonòmics. Generalitat de Catalunya, Barcelona, 2006. 
Es evidente que para facilitar el sentido de esta reforma se precisa una reforma de la jurisdicción ordinaria, como medida que venga pareja a la reforma de la jurisdicción constitucional. Sin esta reforma, que permita instituir al juez y tribunal ordinarios, como sede natural para la garantía de los derechos y libertades, y un sistema ágil de justicia cautelar como procedimiento incidental aplicable a cualquier supuesto, el masivo acceso al recurso de amparo, del que han hecho uso y abuso una parte de los ciudadanos y sus abogados, seguirá siendo una fuente de problemas estructurales para la jurisdicción constitucional.

\section{LUIS MARÍA DÍEZ-PICAZO}

La aspiración de los Magistrados del Tribunal Constitucional a reducir la carga de trabajo que pesa sobre la institución difícilmente podría tacharse de injustificada. Las estadísticas son inequívocas. Es indiscutible que el exceso de trabajo que padece el Tribunal, con el consiguiente retraso en la decisión, viene dado por los recursos de amparo. Todos los demás procesos constitucionales juntos no representan ni el 10\% de los asuntos que le llegan. Cualquier solución que haya de adoptarse pasa, así, necesariamente, por reformar el recurso de amparo. Cosa distinta, por supuesto, es qué tipo de reforma del recurso de amparo es conveniente y deseable, tema que se aborda en otros apartados de este cuestionario.

Dicho esto, creo que no está de más hacer otra observación: los métodos de trabajo del Tribunal Constitucional no parecen haber experimentado grandes cambios desde los tiempos fundacionales de la institución hasta hoy. Hace veinticinco años se sentaron unas pautas de funcionamiento, que básicamente siguen rigiendo actualmente. Tales son señaladamente el informe de admisión que, sobre cada recurso de amparo, elabora un Letrado, así como la deliberación, una vez admitido el recurso de amparo, sobre la base de un proyecto de sentencia redactado por el Magistrado ponente o bajo su supervisión. Ello difiere de lo que es práctica habitual en nuestros otros tribunales, incluido el Tribunal Supremo; y ni que decir tiene que imprime un ritmo necesariamente lento a la tramitación de los amparos, y un tono doctrinal a las sentencias. Estoy seguro de que esos métodos de trabajo estaban plenamente justificados en el período inicial, cuando todo estaba por hacer; pero ahora, con el sofisticado cuerpo jurisprudencial sobre derechos fundamentales que ya poseemos, la inmensa mayoría de los recursos de amparo —incluidos, sea claro, aquéllos que deben ser estimados- no presenta aspectos novedosos ni, por consiguiente, tiene mucho sentido que se siga ese examen tan complejo y solmene. Tal vez fuera aconsejable reservarlo para aquellos casos que de verdad planteen algún problema nuevo, tramitando el grueso de los recursos de amparo de una manera más sencilla. Obsérvese que esto poco tiene que ver con la Ley Orgánica del Tribunal Constitucional, sino con reglas internas - a menudo no escritas- del propio Tribunal.

Siempre en este orden de consideraciones, algún día habría que reflexionar seriamente sobre la escasa simpatía por la oralidad que tiene nuestro Tribunal 
Constitucional. Baste aquí señalar que, como es bien sabido, el gusto por una justicia predominantemente escrita no favorece la agilidad en la resolución de los asuntos.

\section{FRANCISCO JAVIER GARCÍA ROCA}

Me parece plenamente justificado - $\mathrm{y}$ es urgente e insoslayable- disminuir la grave sobrecarga de "pequeños" recursos de amparos que el Tribunal soporta desde hace décadas. Una estadística que por sí sola, dejada a su natural tendencia, no va a decrecer sino que continuará aumentando e incrementando el problema. De suerte que si los grupos parlamentarios no acabaran ahora de consensuar y aprobar una adecuada regulación del proceso, me temo que, por responsabilidad, habrá que hacerlo antes o después y por eso califico la reforma de insoslayable. Unos amparos en su inmensa mayoría nimios o bagatela, en cuanto desprovistos de un objetivo interés constitucional que justifique su enjuiciamiento, y en los que el Tribunal pierde gran parte de su tiempo y esfuerzos, y que dan lugar a sentencias que generan desinterés - o frustraciónentre los lectores de la jurisprudencia constitucional, y que en poco o nada contribuyen a mejorar nuestro sistema de garantías, unos efectos, sin duda, colaterales y no deseados. Su número, por lo demás, crece año tras año cual la bisectriz de un ángulo recto según se sabe desde hace mucho (y en 2006 especialmente, pues puede llegar a ingresar un incremento mucho mayor que en otros años; fueron 7814 en 2004). Algo debe cambiarse - a mi juicio- en la Ley.

En efecto, la elevada cifra de amparos responde a la lógica inherente al diseño legal de 1979, fundado en el principio de subsidiariedad, y era entonces acaso inevitable al carecerse de la experiencia en procesos constitucionales que hoy tenemos. Un acceso directo y subsidiario, no restringido en virtud de limitaciones objetivas ni subjetivas, a instancias de cualquier persona y en cualquier asunto - una escasamente lógica maximización del interés subjetivo en detrimento del interés general, basta prácticamente con agotar la vía judicial previa- que ha llevado a hacer indisociable la titularidad de un derecho fundamental con la legitimación para una acción constitucional y que erige en pretensión el derecho de toda persona a recibir una respuesta sobre el fondo de un único Tribunal Constitucional nacional; no bastando para satisfacer ese interés privado con una multiplicidad de acciones y decisiones judiciales previas. Sin embargo, es evidente que una y otra cosa no son lo mismo. Por el contrario, en un Estado constitucional debe ser el Poder Judicial la sede natural y el verdadero garante de los derechos fundamentales en cualesquiera procesos por su proximidad a los ciudadanos y su organización difusa; y, consiguientemente, el amparo constitucional debe ser excepcional.

El propio Tribunal Constitucional contribuyó a ese entendimiento hipergarantista en su primera época con una jurisprudencia expansiva de las garantías constitucionales en los procesos que favoreció el aumento de los recursos. 
Una fase en la que no fue extraño aseverar que "nada de lo humano nos es ajeno", aforismo que no expresa un criterio de la interpretación constitucional y que situó el listón a una altura que no puede mantenerse. Sin embargo, por duro que sea asumirlo, la función de un Tribunal Constitucional no es impartir justicia, tenemos más de cuatro mil jueces para ello y un legislador democrático que debe estar atento a la mejor configuración de los procesos. Es precisa, en suma, una división del trabajo entre los poderes del Estado. Esa conciencia social y mito sobre el amparo constitucional no podrá mantenerse mucho más tiempo.

El diagnóstico de la enfermedad tras 25 años de experiencias es indiscutible: de los 7951 asuntos ingresados en 2004, 7814 son amparos constitucionales. La cifra supone habitualmente alrededor del 98\% de los asuntos. Nuestro Tribunal Constitucional es un Tribunal de amparo. La paradoja es que normalmente se inadmiten más del 97\% de los amparos y el 85\% por providencia. Se pierde un tiempo preciado en analizar y motivar estas largas providencias de inadmisión, verdaderos autos o "proviautos". De ellos más del 80\% invocan el art. $24 \mathrm{CE}$ en uno de sus dos apartados. Y sólo se estima la demanda entre un 2 o un 3\% de los amparos presentados. Un "lujo constitucional" que no puede seguir pagándose. La propia Presidenta ha dicho que "la situación es alarmante"2.

La situación ha consolidado unas indebidas dilaciones estructurales, sobre todo, en las competencias del Pleno, donde no es extraño que una sentencia se demore a veces diez años ${ }^{3}$, y donde se dificulta notablemente el normal ejercicio de las demás funciones, el control de constitucionalidad de las leyes y los conflictos constitucionales en sus diversas especies, pues el retraso hace que debate procesal envejezca inexorablemente. Unas labores que, paradójicamente, son históricamente las funciones principales y definitorias de la institución, estás sí indefectibles y que no pueden ser ejercidas - como alternativapor los órganos judiciales ${ }^{4}$. La patología - me temo- llega a obstaculizar que este órgano constitucional pueda cumplir bien la función de «intérprete supremo" de la Constitución que le asigna el art. 1.1 de su Ley Orgánica (en adelante, LOTC), al dedicar buena parte de sus decisiones, no a estudiar lo necesario para crear Derecho e interpretar el bloque de la constitucionalidad, sino a enjuiciar o inadmitir miles de asuntos que no demandan realmente una inter-

2 El Mundo, 08.05.2006, p. 19, y encontraríamos afirmaciones parecidas de todas las anteriores presidencias incluso en las Memorias de la institución.

3 Tomando al azar el cuadernillo de jurisprudencia publicado en el BOE el 5 de marzo de 2003, inmediatamente anterior al debate de la ACE del cual se da noticia, una sentencia de Pleno enjuició tres recursos y un conflicto presentados hacía diez años, y otros dos conflictos presentados, respectivamente, en 1995 y 1998, todos ellos acumulados. Las sentencias de amparo dictadas por las Salas resolvieron recursos registrados entre tres y cinco años antes.

4 Bien es verdad que los órganos judiciales pueden colaborar en algunos extremos de menor trascendencia constitucional, puede verse mi trabajo "Conflictos entre el Estado y las Comunidades Autónomas ante el Tribunal Supremo: la competencia diferenciada entre las jurisdicciones constitucional y contencioso-administrativa" en Revista Vasca de Administración Pública, n. ${ }^{\circ}$ 62, 2002, pp. 89-134. 
pretación constitucional, y ya han recibido varias decisiones por parte de los órganos de la justicia.

Se consagra así una modificación, en fase de aplicación y desarrollo, del mismo diseño constitucional, alterando la voluntad del constituyente y del contemporáneo legislador de su ley orgánica que fue la de prefigurar un modelo según el cual el Tribunal Constitucional tuviera pocas, pero importantes funciones. Por el contrario, la institución vive hoy atascada con miles de pequeños asuntos en los que su dimensión subjetiva prima con creces sobre la objetiva. Y un riesgo añadido es que, dada su dimensión preferente de estricta legalidad, son caldo de cultivo de una peligrosa confusión de jurisdicciones y de algunos enfrentamientos notorios con las Salas Primera y Segunda del Tribunal Supremo5. Ese no puede ser el lugar de un Tribunal Constitucional en el nuevo siglo dentro de la división de poderes, y, en cualquier caso, no se adecua a ninguna de las teorías que se han ocupado de estudiar su papel.

La reforma no es pues sólo una "aspiración... de la mayoría de los Magistrados" constitucionales, como se dice en la pregunta, sino algo que impone la tozuda naturaleza de las cosas. En este sentido, el Congreso celebrado por la Asociación de Constitucionalistas de España (ACE) en 2003 en la Universidad Carlos III, tras un sosegado y debatido estudio del problema en varias ponencias, cuyas conclusiones tuve la oportunidad de redactar, se manifestó unánimemente a favor de la reforma del trámite de inadmisión del amparo para permitir que la institución pudiera "seleccionar en positivo" los amparos que debiera enjuiciar ${ }^{6}$.

Mas el legislador todavía no ha sido capaz de resolver el asunto. Hay en esta VIII Legislatura un Proyecto de Ley de Reforma de la LOTC que está en fase de ampliación de enmiendas en la Comisión de Asuntos Constitucionales. Ignoro si finalmente se gestara el deseable consenso parlamentario y llegara a aprobarse. De forma probablemente imprevista, se presentaron más de cien enmiendas sobre las cuestiones más diversas que deben ser leídas con calma. Mi posición es favorable a su aprobación por más que, sin duda, el proyecto sea técnicamente mejorable si uno profundiza en su estudio ${ }^{7}$. Pero en la vida de un

5 Mencionaré sólo dos de los más sonados: los casos de la condena por responsabilidad civil de los Magistrados constitucionales por la Sala Primera del Tribunal Supremo; y la reciente negativa de su Sala Segunda, por un acuerdo no jurisdiccional, a aplicar la doctrina sobre el cómputo para la interrupción de la prescripción de los delitos que había señalado el Tribunal Constitucional al entender que incurría en un exceso de jurisdicción.

6 Cfr La reforma del recurso de amparo, PÉREZ TREMPS, P. (Coord.), con ponencias de E. ALBERTI, M. ARAGÓN, M. CARRILLO y C. VIVER, Tirant lo Blanch, Valencia, 2004, las conclusiones — claramente favorables a la reforma- llevan el título "La cifra del amparo constitucional y su reforma", pp. 273-295.

7 Como muestra, en los conflictos constitucionales no son desdeñables las omisiones del Proyecto. No se arbitra un conflicto legislativo de competencia. No se repara que las Comunidades Autónomas puedan impugnar leyes de otras Comunidades Autónomas lo que genera indefensión. No se mejora la legitimación activa en el conflicto en defensa de la autonomía local. No se solventa la absoluta confusión de jurisdicciones ("alternatividad") en materia de conflictos positivos de competencias con el orden contencioso administrativo. Y no se introducen conflictos negativos de com- 
Estado lo mejor suele ser enemigo de lo bueno y conviene ser posibilista cuando las reformas avanzan en el buen sentido de la marcha. En cuestiones de dirección política de Estado, cual es la regulación y la misma supervivencia de un órgano constitucional, son precisos amplios consensos parlamentarios, y no debe practicarse la función de oposición desde perspectivas estrictamente particularistas, confundiendo el interés general con la suma de un heterogéneo cúmulo de intereses sectoriales: dentro del Estado, los vicios privados no siempre hacen la prosperidad pública, como pretendía la fábula de las abejas de Mandeville.

De aprobarse la modificación, no deberíamos temer serias rebajas en el alto nivel de garantía de los derechos fundamentales de nuestro ordenamiento. No deberían crearse agujeros negros. Me ratifica en esta impresión las labores de un segundo Congreso, organizado por la ACE en la Universidad de Alcalá en el 2005, destinado al estudio de "El amparo judicial de los derechos fundamentales: ¿son necesarias reformas legales?", continuación del anterior sobre el amparo constitucional y cuyas conclusiones igualmente tuve oportunidad de resumir $^{8}$. Se concluyó entonces que los derechos fundamentales se tutelan razonablemente bien por la jurisdicción ordinaria en sus distintos órdenes, sobre todo, a través de cualesquiera procesos ordinarios, pero también de una multiplicidad de amparos judiciales que de forma fragmentaria pero exhaustiva desarrollan el art. 53.2 CE. Me gustaría por eso evidenciar que nuestra ujusticia constitucional" en garantía de los derechos es amplia y difusa y no se circunscribe a la "jurisdicción constitucional concentrada" o monopolio de control de las leyes y de los conflictos constitucionales.

De forma complementaria, si sólo se estiman por sentencia entre un 2 o un $3 \%$ de los amparos constitucionales anualmente presentados, es cabal pensar que - como mucho- será alrededor de esos pequeños porcentajes donde puede haber lesiones constitucionales no detectadas o reparadas por los órganos judiciales. Pero además la inmensa mayoría de esos amparos constitucionales estimados, centrados en las garantías procesales del art. $24 \mathrm{CE}$, derivan de lesiones causadas por la actuación de los órganos judiciales $-\mathrm{y}$ no de otros poderes públicos o privados-, reflejan deficiencias estructurales en el funcionamiento de la justicia y de la administración al servicio de la administración de justicia; viejos lastres que únicamente con imprescindibles mejoras en ese terreno - me temo— podrían realmente arreglarse en el futuro.

No obstante, quizá para evitar un pequeño porcentaje de lesiones de derechos no reparadas, pese a su exclusiva dimensión subjetiva, el mencionado Congreso de la ACE en Madrid defendió que pudieran ser admitidos también, si

petencia a instancias de los Gobiernos de las Comunidades Autónomas, omisión sobre la que ya hubo una proposición de ley en 2002, votada por la mayoría de los grupos y que igualmente produce indefensiones. Ignoro las razones de estos deliberados silencios.

8 El libro, coordinado por P. LUCAS MURILLO y E. CARMONA, se encuentra pendiente de una próxima edición. Las conclusiones que redacté se llaman: "La tutela judicial de los derechos fundamentales a través de cualesquiera procesos y en los amparos ordinarios". 
bien de forma muy excepcional, aquellos asuntos donde pudiera producirse un "grave perjuicio a la parte". Un supuesto que el nuevo art. 50 del Proyecto no contempla. Sin embargo, así ocurre en Alemania, donde el Tribunal Constitucional Federal (desde ahora, BVerfG) debe admitir el recurso también si puede surgir "un grave perjuicio para el solicitante de amparo a causa de la negativa a decidir sobre el fondo" (art. 93a.2.b] de su Ley), y se entiende una variante de la función de garantía de los derechos. Albergo dudas de que estos supuestos de "grave perjuicio" no debieran configurar también una causa de admisión. Pero existe igualmente el riesgo, en sentido contrario, de que este motivo subjetivo de admisión fuera un "colador", y al desbordarse hiciera ineficaz la objetivación del amparo constitucional que la reforma postula. No es fácil decantarse...

De forma paralela está en el Congreso de los Diputados asimismo un proyecto de reforma de la Ley Orgánica del Poder Judicial (en adelante, LOPJ) por el que se modifica el recurso de casación y se generaliza la doble instancia penal, mediante un recurso de "apelación limitada", que permitiría satisfacer el derecho al doble grado de jurisdicción en el orden penal previsto en el art. 14 del Pacto Internacional de Derechos Civiles y Políticos y en el art. 2 del Protocolo Adicional 7 al Convenio Europeo de Derechos Humanos. Dado que, en 2004, 2.956 amparos de los 7.814 ingresados procedieron de ese orden jurisdiccional (un alto 37'8\% de los recursos), es razonable esperar que tal medida legal, de prosperar, contribuyera a paliar el grifo de los recursos sobre violaciones de derechos en los procesos penales que llegan al amparo actualmente y que quizá no puedan obtener reparación en virtud del limitado, y a estos efectos inadecuado, recurso extraordinario de casación.

Por otra parte, el nuevo art. 37 del Proyecto de reforma de la LOTC permite a las partes en el procedimiento judicial $a$ quo personarse ante el Tribunal Constitucional tras ser admitida a trámite una cuestión de inconstitucionalidad para formular alegaciones. Probablemente un futuro cierre del grifo de los amparos podría compensarse con una mayor flexibilidad en la regulación de las cuestiones de inconstitucionalidad; como de algún modo ocurre en Italia donde el amparo no existe y la cuestión debe elevarse por el órgano judicial si no está "manifiestamente infundada", lo que más sencillo que demostrar que la ley "pueda ser contraria a la Constitución" como se le pide en España. Particularmente, las suscitadas a instancias de parte con el fin de facilitar a los justiciables poder razonablemente imputar a la ley muchas de las lesiones que actualmente atribuyen al juez en bastantes amparos. Volveré sobre la reforma de la cuestión de inconstitucionalidad más adelante.

\section{ÁNGEL GARRORENA MORALES}

La reforma de la LOTC que en este momento está en curso se produce cuando se ha cumplido un cuarto de siglo desde que el Tribunal Constitucional español comenzara a funcionar. En estos veinticinco años, como consecuencia sin duda de la propia experiencia del Tribunal, la LOTC ha sido modificada ya 
en cinco ocasiones. No obstante, esas reformas (salvo quizás, y aun ello sólo en parte, la de 1988) han tenido siempre un alcance puntual y concreto, con lo cual la mayoría de los problemas que arrastra esta institución han llegado hasta el presente sin que el legislador los encare de una forma eficaz y decidida. Lo que singulariza, pues, a esta modificación que ahora se intenta es que, por primera vez desde 1981, la reforma del Tribunal Constitucional se plantea con la ambición de constituir una revisión general del derecho que lo rige. Eso, al menos, es lo que se deduce de la exposición de motivos con la que se abre el proyecto de reforma que comentamos: "las mencionadas modificaciones — se lee en su texto, en referencia a las cinco reformas habidas hasta hoy- no babian acometido basta el momento una reforma que afrontase de manera conjunta las dificultades de funcionamiento del Tribunal Constitucional, que es el objetivo de esta ley orgánica". Quiere ello decir, por tanto, que el cometido de dicha reforma no es tan solo, ni mucho menos, la revisión del recurso de amparo. Muchas otras cuestiones, relativas a otros procesos o al funcionamiento del Tribunal en general, entran igualmente en el ámbito de sus propuestas. Sin embargo, haríamos mal en deducir de esta notoria amplitud de miras del proyecto que las referencias que el mismo hace al amparo no constituyen el núcleo duro de la reforma y que la modificación de dicho recurso no es su principal razón de existir. Lo contrario es más cierto. Tal vez por ello, la parte más extensa de este cuestionario se mueve en torno a este tema.

La primera pregunta que la encuesta nos plantea incluye dos cuestiones para las que su texto parece presumir una respuesta alternativa, como si la solución de una de ellas debiera comportar la resignación frente a la otra, cuando la verdad es que ambas apuntan a objetos no diré que desconectados pero sí distinguibles. En primer lugar, nos pide que nos pronunciemos sobre si la aspiración del Tribunal Constitucional a reducir el elevado número de recursos de amparo que hoy tiene que tramitar está o no suficientemente justificada, lo que, conocida la realidad, parece inducir en quien contesta una respuesta positiva. En cambio, acto seguido, se nos inquiere sobre la posibilidad de que semejante recorte en el número de amparos que llegan al Tribunal constituya una disminución sensible en el grado de protección del que hoy disponen nuestros derechos y libertades, lo que, por el contrario, produce en el encuestado una cierta sensación inversa, casi de desconfianza frente a las nocivas consecuencias que pudieran derivarse de esa reducción de demandas de amparo por la que en un momento anterior había apostado.

Puesto, pues, a contestar tales cuestiones, y a distinguir en ellas lo que haya que distinguir, creo que a la primera pregunta hay que responder de forma indudablemente afirmativa, sin que haya que perder demasiado tiempo en explicarlo, ya que éste es un tema que ha pasado a tener un planteamiento casi tópico. No en vano, para todo el mundo es claro que la recepción por el Tribunal Constitucional de 7.814 demandas de amparo en un solo año (por atenernos a las cifras que refleja la última Memoria del Tribunal, la de 2004) es un severo problema, aunque sólo sea por razones cuantitativas. Nadie desconoce, además, que el rechazo a limine, en ese mismo año, de 6.431 recursos me- 
diante auto o providencia de inadmisión es una muestra palpable del mal diseño que el legislador dio desde un principio a este proceso. Y ningún conocedor avezado de esta cuestión ignora, en fin, que el hecho de que 6.523 demandas - un $83,84 \%$ del total de las registradas en este periodo- tengan que ver con la invocación del artículo 24 de la CE es un nuevo signo del defectuoso funcionamiento actual del amparo, cuya corrección no cabe dilatar. En resumidas cuentas, nada que no sepamos todos con meridiana certeza y desde hace tiempo. De ahí que crea que la preocupación mostrada por los magistrados del Tribunal Constitucional —y no sólo por ellos- respecto de esta situación está mas que justificada y que a este mal estado de cosas hay que ponerle remedio si no se quiere que el excesivo tiempo que el Tribunal está teniendo que dedicar a desestimar e inadmitir recursos de amparo le impida atender como es debido a otras responsabilidades.

A la primera parte de la pregunta respondo, pues, que sí. Ahora bien, una vez ello resuelto, ¿cabe concluir de aquí que esta conveniente racionalización del número de amparos debe redundar de modo necesario en una reducción significativa de la protección de la que hoy disponen nuestros derechos fundamentales? Y es a esta segunda parte de la pregunta a la que pienso que no cabe dar una respuesta tan segura y exenta de distingos como la que acabamos de ver que procede respecto de la primera, con lo cual mi contestación en este caso sería que depende, porque va de suyo que ese indeseable resultado (el descenso de la protección de nuestros derechos), si se produjera, no se deduciría del hecho de que el número de recursos que llegan al Tribunal hubiera disminuido sino del modo en que tal disminución se hubiera logrado, de donde es a este último extremo, y no a esa reducción misma, al que hay que atender para formular una respuesta fundada.

Lo que sí está claro es que, si la técnica empleada para ello es la que ahora proponen los artículos 49.1 y 50.1,b) del proyecto de reforma que nos ocupa, esto es, una objetivación del recurso según la cual sólo se admitirán a trámite aquellas solicitudes de amparo que merezcan un pronunciamiento "en razón de su especial trascendencia constitucional,, esa reducción se va a producir de manera inexorable. Y ello no porque tal fórmula sea mejor o peor que cualquier otra sino porque, por definición, optar por la objetivación del recurso de amparo supone dar a éste un giro de $180^{\circ}$ en virtud del cual su admisión deja de ser, sencillamente, un derecho del recurrente conectado a la posible existencia de una lesión en sus derechos fundamentales y pasa a ser una decisión del Tribunal Constitucional en la que juegan ya unos parámetros muy distintos.

La cuestión, por tanto, es saber si existe otro tipo de planteamiento que, sin causar tal desprotección subjetiva de nuestras libertades fundamentales, nos permita alcanzar idéntico o similar resultado a la hora de liberar al Tribunal Constitucional de su imposible carga presente. Pero de esto hablaremos mejor en las respuestas que siguen. 


\section{JESÚS GONZÁLEZ PÉREZ}

1. La situación actual del TC es insostenible. Un Tribunal integrado por doce miembros - y creo que son demasiados—, por numeroso y preparado que sea el personal colaborador, no puede decidir en plazos razonables los miles de procedimientos que se incoan ante él: 6.901, en 2000; 6.934, en 2001; 7.456, en 2002; 7.878, en 2003, y 7.951 en 2004. Si siempre la demora en la decisión de los litigios es un atentado al valor Justicia, que es el segundo, después de la libertad, de los valores superiores que proclama el artículo $1 .^{\circ}$ de la Constitución, en máximo grado se producirá si se produce en los procedimientos a través de los cuales realiza el Tribunal las funciones que le asigna el art. $161 \mathrm{CE}$.

En los de constitucionalidad, porque supone mantener durante los años en que se concreta la incertidumbre de multitud de situaciones jurídicas derivadas de la Ley cuestionada, hasta que, una vez pronunciada la sentencia con valor de cosa juzgada y publicada en el BOE produzca efectos generales. Con el grave riesgo de que cuando llegue, se hayan creado situaciones irreversibles (en aplicación del art.40 LOTC), salvo que, en el proceso ordinario, se hubiere planteado la cuestión de inconstitucionalidad o que el órgano judicial, teniendo conocimiento de que está pendiente de decisión ante al TC la supuesta inconstitucionalidad, hubiere paralizado de hecho el procedimiento, aunque la Ley procesal no lo autorice.

En los de amparo, porque es evidente la inutilidad de un proceso cuyo objeto es proteger derechos y libertades como la libertad ideológica, la intimidad, la libre circulación por el territorio nacional o cualquier otro, muchos años después de producirse los atentados.

Y en los conflictos constitucionales, porque el normal funcionamiento del Estado y Autonomías y órganos constitucionales, exige la rápida decisión de cualquier duda sobre sus esferas de competencia.

Es necesario, por tanto, poner fin a la situación actual, reduciendo el ámbito de la jurisdicción del TC.

2. En consecuencia, es lógica la aspiración ya tradicional de los Magistrados del TC de tramitar un menor número de recursos de amparo.

Ahora bien, no creo que la fórmula de reducir el número de amparos sea la idónea para descargar de trabajo al Tribunal y dejarlo reducido a un número de procedimientos que, razonablemente, pueda decidir con la celeridad que exige la naturaleza de las cuestiones sobre las que versan. Porque, por muy clara que sea la Ley al determinar los supuestos en que es admisible el amparo, la insatisfacción de las partes que en un proceso no han obtenido una sentencia favorable a sus pretensiones, no se resistirán ni conformarán con la decisión última de los Tribunales ordinarios y forzarán a los Abogados — cuando no son éstos los que los promueven- a interponer recursos de amparo descabellados, que siempre obligarán a decidir sobre su inadmisión, absorbiendo una buena parte del tiempo de los Magistrados a esta tarea, por grande que sea la colaboración de los Letrados. Un Magistrado del TC me ha reconocido que estos trámites agotan la mitad de su tiempo. 
Y lo que en modo alguno es admisible es que un Tribunal que, como el Constitucional, que ha dicho que el derecho a la tutela judicial efectiva no puede ser comprometido y obstaculizado mediante la imposición de formalismos enervantes o acudiendo a interpretaciones de las normas que regulan las exigencias formales claramente desviadas del sentido propio de tales exigencias o requisitos, utilice los formalismos para inadmitir las demandas de amparo que ante él se formulan, para que en la práctica de los últimos años las admisiones no excedan del 4 por 100, por lo general, algo más del 2 por 100.

Es cierto que, como se señaló, los recursos de amparo descabellados no merecen otro trato que la declaración de inadmisibilidad frontalmente. Como así se hace. Pero hay también amparos de fundamento incuestionable. Y cada día más, ante el formalismo desatado por el Tribunal Supremo para evitar los recursos de casación que ante él se acumulan y asfixian a la Justicia. Y estos amparos, en su mayor parte, no llegan a admitirse.

He de reconocer que esto no ocurre siempre así. Pues hay veces en que el amparo salva esa trinchera inicial y hasta llega a ser estimado, remediando la injusticia. Pero en muy pocas veces. Poquísimas veces. Por lo general, la injusticia se consuma.

Según la normativa propuesta en el proyecto de Ley de reforma del TC en trámite parlamentario, se atribuye la decisión sobre la no admisión a la Sección si ésta lo acuerda por mayoría; pero si la mayoría lo que decide es la admisión, entonces ha de trasladar la resolución a la Sección (art. 50). Lo que pone de manifiesto cuál es la orientación de la reforma. Pero lo grave no es esto. Lo grave está en que una de las causas de inadmisión es que la demanda incumpla un requisito que exige el art. 19.1: que justifique «la especial trascendencia constitucional del recurso", que el Tribunal (la Sección si lo que acuerda es la inadmisión) «apreciará atendiendo a su importancia para la interpretación de la Constitución, para su aplicación o para su general eficacia, y para la determinación del contenido y alcance de los derechos fundamentales". En realidad, queda al criterio de la mayoría de los Magistrados de la Sección - y, quizás, en la práctica, en muchos casos al del Letrado del Tribunal correspondientedecidir sobre la inadmisión.

Si tenemos en cuenta que hasta la fecha no ha sido muy respetuoso el Tribunal con el principio de igualdad y ha jugado un papel importante la personalidad del demandante a la hora de decidir los amparos, podemos imaginarnos cómo va a apreciarse la "trascendencia constitucional" para pronunciarse sobre la admisibilidad del amparo.

3. Creo que la solución no radica en reducir el número de amparos, sino en la eliminación de éste del ámbito de la jurisdicción del TC. Para lo que, por supuesto, no basta una Ley orgánica, sino que es necesaria la reforma de los arts. 53.2, 161 y 162 CE. Así lo mantuve en mi intervención en la Academia de Ciencias Morales y Políticas el curso 2005-2006. En definitiva, esta supresión solo supondría ajustar las funciones al esquema de constitucionalidad concentrado en un Tribunal de superior rango tal y como fue diseñado por Kelsen. Y así se adujo a lo largo de la elaboración del texto constitucional, con la opo- 
sición de algunos parlamentarios que se atribuyeron poder constituyente, a que conociera de las violaciones de los derechos fundamentales, más que por lo que podría suponer apartamiento de un esquema de jurisdiccional, por razones prácticas.

Sin duda, fue una enmienda de Lorenzo Martín-Retortillo la que con mayor precisión formuló los graves inconvenientes que supondría esta atribución al Tribunal Constitucional de los recursos de amparo. Pueden resumirse así:

- La extensión de la jurisdicción contencioso-administrativa, sin restricciones, cubriría con creces la necesidad de un control de la actuación de los Poderes públicos, como sucede en otros países.

- Tal atribución supondría una carga tal para el TC, que le dificultaría ejercer su jurisdicción en aquellas materias que le son propias.

- En consecuencia, es preferible potenciar la jurisdicción ordinaria, superar la inseguridad, la duración, incluso la carestía de los pleitos y buscar fórmulas enérgicas de protección jurisdiccional.

El también Senador Angulo Montes formuló asimismo una enmienda in voce ante la comisión aduciendo otra razón: "la conflictividad presumiblemente derivable de la concurrencia en identidad de materia de dos jurisdicciones que deben mantenerse como corresponde a su distinta naturaleza: judicial y ordinaria la una, constitucional y política la otra". Además insistía en la necesidad de "evitar que se desnaturalice —el TC- por exceso de competencias". Y aunque la doctrina acogió favorablemente esta posibilidad de amparo, no faltaron quienes consideraron prudentes y acertadas las enmiendas formuladas en contra. Como Fernando Garrido Falla, al comentar el artículo 53 de la Constitución, y decir: "Con su característico buen sentido jurídico, demostrado en sus frecuentes intervenciones, el profesor Martín-Retortillo defendió ante la Comisión de Constitución del Senado la pura y simple supresión del recurso de amparo. Sus argumentos, desde el punto de vista jurídico, eran irrebatibles: si actualmente se establece una jurisdicción contencioso-administrativa sin restricciones, basada en la cláusula general ¿qué queda para un recurso de amparo que ha de ser tramitado y resuelto nada menos que por el Tribunal Constitucional?".

La práctica ha venido a dar plenamente la razón a tan ponderadas objeciones.

El amparo, tal y como está configurado en nuestro Ordenamiento, no constituye la vía eficaz para la protección de los derechos fundamentales, aun cuando la decisión de los procedimientos tuviera lugar en plazos brevísimos, lo que, por otro lado, resulta imposible si el TC sigue siendo lo que es y debe ser. Para la protección de los derechos fundamentales y libertades públicas están los Tribunales que integran el Poder judicial, a través del proceso basado en los principios de preferencia y sumariedad que prevé el art. 53.2 CE, que, desgraciadamente, no existe. En realidad, con una buena regulación de las vías procesales para hacer efectiva la protección de los derechos fundamentales ante los 
Tribunales ordinarios resultaría innecesario el amparo ante el Tribunal Constitucional. Como dijo Javier Delgado-Barrio, siendo Presidente del Tribunal Supremo, en el discurso de apertura de Tribunales del año 2000, unna normativa que cubriese todos los supuestos de violación de aquellos derechos atribuible al juez, podría implicar para ellos la innecesariedad del amparo". No hay razón para que cuando sean Jueces o Tribunales los que lesionen un derecho fundamental no sean Jueces y Tribunales los que velen por su protección a través de los recursos que, en su caso, se establezcan. No hay razón alguna para que, por encima del Tribunal Supremo, que es el superior en todos los órdenes, según el art. 123.1 CE, exista un órgano que controle y revise su actuación y la de los otros de inferior jerarquía. No tiene sentido la desconfianza hacia los Jueces y Magistrados que ha estado latente, al menos en un principio, en la actuación del Tribunal Constitucional. No se olvide que fue esta desconfianza la razón decisiva de la atribución de esta jurisdicción al Tribunal Constitucional, como reconoció uno de sus primeros Presidentes, Tomás y Valiente: «hubiera sido un grave error confiar en 1978 - dice-, con la composición personal que entonces tenía de poder judicial y más en particular el Tribunal Supremo, la protección última (el subrayado es del autor) de los derechos fundamentales a los Tribunales ordinarios". No tenía sentido entonces esta desconfianza. Y menos sentido tiene ahora.

Por otro lado, ha de tenerse en cuenta que por exquisito que sea el cuidado con que el Tribunal Constitucional ejerza las funciones que actualmente tiene atribuidas en orden a la protección de los derechos fundamentales frente a las violaciones que tuvieran su origen en acto u omisión de un órgano judicial, por grande que sea el celo a la hora de limitar la jurisdicción del Tribunal Constitucional a sus justos límites, los conflictos son inevitables. Como así ha saltado frecuentemente a los medios de comunicación, habiendo dado lugar a reuniones de los Presidentes del Tribunal Supremo y del Tribunal Constitucional, y hasta que se haya llegado a pedir que se apele al Jefe del Estado como árbitro y moderador del regular funcionamiento de las instituciones, como establece el artículo 56.1 CE.

Y esos conflictos, ¿por qué? ¿Por qué tan solo un ínfimo número de amparos llegan a buen fin y logran reparar, aunque muy tardíamente, alguna injusticia? Mientras tantos y tantos quedan sin reparar.

\section{PABLO LUCAS MURILLO DE LA CUEVA}

Más que una aspiración de los Magistrados, como dice la pregunta, creo que adoptar medidas para reducir el número de recursos de amparo es una necesidad objetiva del propio sistema de protección de los derechos fundamentales. Necesidad, por cierto, cada vez más claramente perceptible como lo corrobora el hecho de que se ponga de manifiesto reiteradamente en cuantas sedes, sean académicas, profesionales o institucionales, se aborda la cuestión.

Dicho esto, no creo que, de prosperar iniciativas como la que está en trámite en las Cortes Generales, exista el peligro de que se reduzca el nivel de tu- 
tela de esos derechos. Las cifras recogidas en las Memorias del Tribunal Constitucional reflejan que la inmensa mayoría, muy por encima del 90\%, de los recursos de amparo que se interponen son inadmitidos. Eso quiere decir que, en términos generales, los Tribunales de Justicia han dado —están dando— a los recurrentes la tutela que el ordenamiento jurídico está en condiciones de ofrecerles. Por tanto, no tiene sentido mantener un estado de cosas que fuerza a los Magistrados del Tribunal Constitucional a dedicar buena parte de su tiempo al trámite de admisión de recursos de amparo que no tienen posibilidad de prosperar.

\section{REFORMAS DE LA JURISDICCIÓN ORDINARIA Y RECURSO DE AMPARO}

2. ¿En qué medida la reforma de la jurisdicción ordinaria y, más en concreto, del incidente de nulidad de actuaciones pueden reducir el número de recursos de amparos ante el Tribunal Constitucional?

\section{MARC CARRILLO}

La reforma del incidente de nulidad de actuaciones previsto en el artículo 241 de la Ley Orgánica 6/1985, de 1 de julio, del Poder Judicial (LOPJ), responde, en principio, a una lógica objetivamente positiva, que es la de reforzar la posición de la jurisdicción ordinaria como garante habitual de los derechos fundamentales. Es una forma más de incentivar la posición de los juzgados y tribunales como sede natural o instancia habitual, de tutela de los derechos y libertades de los ciudadanos. Teóricamente, es una vía más para reafirmar el amparo judicial y reforzar el carácter subsidiario del amparo constitucional.

La reforma que introduce la Disposición Adicional 1. ${ }^{a}$ del Proyecto consiste en ampliar el ámbito material del planteamiento del incidente de nulidad de actuaciones a la vulneración de cualquier derecho fundamental y no sólo, como hasta ahora, a los supuestos de indefensión o incongruencia que puedan darse en una decisión judicial. Parece, pues, obvio que con este instrumento procesal se trata de atribuir un mayor protagonismo a la jurisdicción ordinaria en la tutela de los derechos fundamentales, reforzando el llamado amparo judicial. Sin embargo, la incógnita que se cierne sobre la bondad de esta medida es la respuesta que den a su aplicación, — precisamente- los órganos judiciales a los que va destinada y a los que se imputa la nulidad de sus actuaciones por un acto de especial trascendencia, cual es la lesión de un derecho fundamental. En efecto, el incidente de nulidad de actuaciones se puede plantear de forma excepcional por quienes sean parte legítima o hubieran debido serlo en un proceso, siempre que no haya podido denunciarse antes de recaer solución que ponga fin a aquél y, además, siempre que dicha resolución no sea susceptible de recurso ordinario ni extraordinario. La competencia para conocer del incidente corresponde al mismo juzgado o tribunal que dictó la resolución 
que hubiere adquirido firmeza. Por tanto, es el mismo órgano judicial el que, en su caso, debe reconsiderar una decisión propia porque en ella puedan darse indicios de lesión de derechos fundamentales. Y no sólo de aquéllos que se refieren a la tutela judicial que deben dispensar, sino también del resto de los derechos fundamentales reconocidos por la Constitución.

El eventual éxito de esta medida se cifra en la asunción por jueces y tribunales de una nueva cultura jurisdiccional, en la que se asuma como propia la posibilidad de la nulidad de los actos jurisdiccionales. Ciertamente, con la cultura jurisdiccional dominante, no es nada sencillo que ello vaya a aplicarse con fluidez, por quien son los autores de la decisión. Sin embargo, un buen acicate para evitar el incidente de nulidad ha de ser una mayor aceptación por la jurisdicción ordinaria de la jurisprudencia del Tribunal Constitucional en materia de derechos fundamentales, cuando aquélla constituye una línea interpretativa consolidada. Desde luego, esta regla de comportamiento jurisdiccional no tiene por qué ir en detrimento de la independencia del juez, ya que su discrepancia de la jurisprudencia constitucional no está excluida, pero en todo caso, de producirse, la deberá motivar adecuadamente.

Por otra parte, el incidente de nulidad de sus actuaciones, de ser admitido a trámite, lógicamente, no impide al órgano judicial la capacidad de decidir sobre la ejecución y eficacia de su decisión. En este sentido, ésta no queda en suspenso, salvo que sea el propio juez o tribunal el que, a la luz de la nueva situación creada, pueda acordar una medida cautelar de suspensión.

Conviene poner de relieve otra cuestión relacionada con el incidente de nulidad de actuaciones. Porque, en la medida en que el incidente de nulidad podrá plantearse respecto de cualquier derecho fundamental, merece la pena subrayar que el Proyecto de reforma de la LOTC no aborda un aspecto de la tutela de los derechos fundamentales que ya debería ser indeclinable. Se trata, por supuesto, del amparo frente a lesiones de derechos en las llamadas relaciones jurídicas horizontales o inter privatos, y el eventual acceso de la demanda de amparo ante el Tribunal Constitucional, cuando la jurisdicción ordinaria lesiona el derecho fundamental a la tutela judicial. La experiencia que en este sentido ofrece la jurisprudencia constitucional sobre las diversas situaciones de vicios in procedendo y de vicios in indicando respecto del derecho a la tutela judicial, debería obligar a que el legislador de la reforma de la LOTC, considerase la oportunidad de incorporar la regulación de los supuestos de amparo en la relaciones jurídico-privadas, a fin de disponer de un parámetro útil para decidir sobre la procedencia o no del incidente de nulidad de actuaciones también en estos casos.

\section{LUIS MARÍA DÍEZ-PICAZO}

Tengo serias dudas de que la reforma de la jurisdicción ordinaria y, en particular, del incidente de nulidad de actuaciones sirva para resolver la avalancha de amparos. Las razones de este escepticismo son tres. 
En primer lugar, el incidente de nulidad de actuaciones existe ya, con una regulación muy similar a la que se propone en la reforma de la Ley Orgánica del Tribunal Constitucional. La novedad es que ahora se extiende a cualquier violación de los derechos susceptibles de amparo -incluidos los derechos fundamentales ajenos al art. $24 \mathrm{CE}$ - y no se limita, como hasta ahora, a la incongruencia y la indefensión. Pero la verdad es que el actual incidente de nulidad de actuaciones no ha servido ni siquiera para reducir el número de amparos por incongruencia omisiva o por lesión de las garantías de defensa.

En segundo lugar, el incidente de nulidad de actuaciones se resuelve, tanto en su regulación actual como en la que se propone con la reforma, por el mismo órgano jurisdiccional que dictó la resolución firme. Y la experiencia enseña que es muy difícil que un juez o tribunal estime que, efectivamente, incurrió en una vulneración de derechos fundamentales o no reparó la perpetrada por otro. En otras palabras, fiar la reforma del amparo a la capacidad de autocrítica de los tribunales ordinarios no me parece muy realista.

En tercer lugar, el incidente de nulidad de actuaciones no se presenta como una alternativa al recurso de amparo, sino como un escalón más de la vía judicial previa que hay que agotar para poder acudir al Tribunal Constitucional en amparo. El recurso de amparo sigue siendo, en todo caso, posible. Por ello, la exigencia de haber intentado la nulidad de actuaciones no tendrá efectos disuasorios, o no los tendrá en una escala lo suficientemente grande como para reducir el número de amparos que llegan al Tribunal. Este nuevo requisito, además, puede traer consigo una ulterior sobrecarga de trabajo sobre los tribunales ordinarios, y un alargamiento global de la duración de los pleitos en que se ventilan problemas de derechos fundamentales.

Mi opinión es que, si de verdad se quiere que la jurisdicción ordinaria libere al Tribunal Constitucional de gran parte del peso que supone la tutela de los derechos fundamentales, habría que buscar soluciones alternativas al recurso de amparo constitucional, no endurecer la vía judicial previa a éste. ¿Cuáles podrían ser esas soluciones? De esto se habla en otro apartado del presente cuestionario. Pero es claro que debe tratarse de alternativas, nunca de complicar ulteriormente la actual regulación del amparo.

\section{FRANCISCO JAVIER GARCÍA ROCA}

No será en ningún caso bastante para solventar la sobrecarga de amparos constitucionales con una nueva regulación del incidente de nulidad de actuaciones. El asunto no es tan sencillo. Si buscamos adoptar un paquete de medidas que solucione el problema, es menester — como he explicado antes- cerrar primero el caudal del acceso directo sin trascendencia constitucional. Las soluciones al desbordamiento del amparo constitucional deben buscarse dentro de esa sede y no fuera, en la jurisdicción ordinaria. Ésta fue una de las conclusiones — quizá inesperada - del segundo seminario de la ACE celebrado en la Universidad de Alcalá sobre las posibles reformas del amparo judicial. La me- 
jora de este incidente quizá ayudará a resolver, sobre todo, indefensiones procesales ligadas a las distintas vertientes del art. $24 \mathrm{CE}$. Y en este aserto coinciden igualmente las conclusiones esbozadas en esas jornadas. Mas una adecuada regulación de este remedio procesal dista de ser simple como pudiera parecer a primera vista.

El Proyecto dispone una modificación del incidente de nulidad de actuaciones (Disposición Final Primera) como vía previa al amparo, y pretende reformar por enésima vez el art. 241 de la LOPJ. Cabría ahora este incidente cuando se pida que se declare una nulidad "fundada en cualquier vulneración de un derecho fundamental de los referidos en el art. 53.2 CE", y "siempre que no haya podido denunciarse antes de recaer resolución que ponga fin al proceso y siempre que dicha resolución no sea susceptible de recurso ordinario ni extraordinario". Como se recordará, la actual versión del art. 241, modificado por Ley Orgánica 19/2003, de 23 de diciembre, establece que no se admitirán con carácter general incidentes de nulidad de actuaciones, y que, sin embargo, excepcionalmente, quienes sean parte legítima o hubieran debido serlo, podrán pedir por escrito que se declare la nulidad de actuaciones "fundada en defectos de forma que hayan causado indefensión o en la incongruencia del fallo". La Ley actual posee pues un objeto mucho más limitado o restringido que el que postula la reforma.

El principal reparo que se puede formular a la nueva regulación del incidente está en el terreno de su eficacia, acaso no sea muy probable que el mismo órgano judicial que ha producido la lesión del derecho, o no la ha reparado, poco tiempo antes alcance un suficiente distanciamiento como para, inmediatamente después, al tramitar este incidente, cambie de criterio y subsane la irregularidad cometida o repare la lesión. No es muy probable. Puede, sin embargo, que tenga eficacia para evidentes situaciones materiales de indefensión, incongruencias y otras irregularidades procesales que pueden haber pasado desapercibidas al órgano judicial. Quizá debería resolver el incidente un órgano judicial distinto con mayor jerarquía. Pero temo no tener aquí soluciones...

En cuanto a la adopción de reformas más generales de la jurisdicción ordinaria, tampoco es sencillo regular nuevos amparos judiciales y puede que ni siquiera sea conveniente. En primer lugar, a la vista de la experiencia adquirida en estos más de veinticinco años, parece haber una amplia mayoría doctrinal que estima que no cabe un único desarrollo, directo y por ley del art. 53.2 CE, del llamado amparo judicial, y considera inevitable la existencia de una diversidad de regulaciones. La sucesiva derogación de la Ley 62/1978, de 26 de diciembre, de protección jurisdiccional de los derechos fundamentales de la persona, por una pluralidad de leyes reguladoras de cada uno de los órdenes jurisdiccionales así lo confirma. Una multiplicidad de leyes tan heterogénea como es la misma naturaleza de los derechos fundamentales. Tenemos muy diversos amparos judiciales en una larga docena de leyes de las que no me puedo ocupar aquí, pero que fueron estudiados con calma en el citado Congreso de Alcalá. Y, en segundo lugar, parece apreciarse una creciente tendencia —en contra de lo que habíamos creído en los primeros años de desarrollo constitu- 
cional- a garantizar los derechos fundamentales en los procesos ordinarios y junto a las cuestiones de legalidad y no por procesos necesariamente específicos, aunque ciertamente estos amparos judiciales no deban desaparecer.

\section{ÁNGEL GARRORENA MORALES}

Trasladar a la jurisdicción ordinaria buena parte de la carga que ahora soporta el Tribunal Constitucional en materia de amparo, será siempre una buena idea. Diría incluso que ésta es la única solución sensatamente explorable a la que cabe acudir para dar respuesta a los problemas que intenta atajar el actual proyecto de reforma de la LOTC. Vista desde múltiples ángulos, esta fórmula ofrece, en efecto, notables ventajas. Es apta, desde luego, para reducir el exceso de trabajo que hoy agobia al Tribunal Constitucional, porque desplaza esa carga a otras instancias; consigue además que tal alivio no redunde en una simétrica desprotección de nuestros derechos fundamentales, porque quien recibe esa tarea la asume con idéntico sentido protector; y, por si ello fuera poco, la solución que mencionamos repone, en fin, a los jueces ordinarios en su condición de efectivos garantes "naturales" de los derechos de los ciudadanos, ahí incluidos sus derechos fundamentales, lo que, de paso, es una buena forma de corregir esa imagen inexacta e injusta que, sin quererlo, ha ayudado a generar el recurso de amparo al inducirnos a pensar que la defensa de nuestros derechos fundamentales y libertades públicas no encuentra suficiente satisfacción en el trabajo de nuestros jueces y que por eso existen el recurso de amparo y el Tribunal Constitucional.

A este planteamiento responde, pues, con buena lógica, la disposición final primera del proyecto que comentamos cuando intenta modificar el apartado 1 del artículo 241 de la Ley Orgánica 6/1985, del Poder Judicial, para permitir que quienes sean (o hayan debido ser) parte legítima en un determinado proceso puedan plantear ante el juez ordinario, y antes de acceder al Tribunal Constitucional, el incidente de nulidad de actuaciones precisamente fundado en la presunta existencia de cualquier lesión en alguno de sus derechos fundamentales protegidos en amparo ("en cualquier vulneración de un derecho fundamental de los referidos en el artículo 53.2 de la Constitución", dice el proyecto), y no, como prevé su redacción actual, basado tan solo en la estricta alegación de aquellos "defectos de forma que hubieran causado indefensión o en la incongruencia del fallo". En la filosofía del proyecto parecería incluso que este giro rotundo que se da a la concepción y al sentido de tal incidente es la fórmula a la que el futuro legislador intenta recurrir para compensar la evidente disminución de protección subjetiva de los derechos fundamentales que, según vimos en la respuesta anterior, la objetivación del recurso de amparo va a terminar por comportar. Es así porque, si el Tribunal Constitucional se va a desentender a partir de ahora de la lesión individual de los derechos para limitarse a admitir aquellos casos en los que su pronunciamiento pueda tener un alcance objetivo, es lógico que el incidente de nulidad de actuaciones aparezca, en la 
economía total del proyecto y en la intención de sus autores, como la medida procesal capaz de conseguir que el particular cuente, en sustitución de lo que pierde, con una posibilidad más — ahora además última, si el supuesto no suscita un interés objetivo- de defender sus derechos fundamentales ante la jurisdicción ordinaria.

No digo, pues, que esta pieza carezca de encaje en la lógica global del proyecto. No obstante, aun compartiendo con sus autores el convencimiento de que la solución al colapso que hoy padece el Tribunal Constitucional pasa por trasladar cometidos a la jurisdicción ordinaria, no me parece que la utilización del incidente de nulidad de actuaciones sea la estrategia más acertada para lograr dicho fin. No lo es, creo, por múltiples razones que paso a enumerar:

a) Ante todo, porque el incidente de nulidad de actuaciones ha sido concebido siempre -lo que es lógico, ya que ésta es su más exacta condición- como un instrumento extraordinario utilizable contra infracciones o vicios de carácter procesal, esto es, como un remedio frente a defectos de forma ocasionados en el procedimiento, y nunca como un proceso sustantivo y autónomo, con lo cual pretender ahora que juegue el papel que debería corresponder a un auténtico proceso singular y específico (y además a un proceso cuyo delicado objeto es la defensa de todos nuestros derechos fundamentales; ni siquiera sólo de nuestros derechos de carácter procesal) tiene bastante de forzado y yo diría incluso que de sorprendente.

b) Además, los antecedentes de esta figura tampoco respaldan la elección que hacen los autores del proyecto al incluirla en sus planes; recordemos que la existencia misma de este incidente está sometida desde hace tiempo a un serio debate en la doctrina y que son muchos los autores que le ven más inconvenientes (utilización obstruccionista del mismo, alargamiento innecesario del proceso...) que ventajas. De hecho, su asunción por la legislación procesal española ha sido significativamente vacilante e insegura; tanto que la Ley 34/1984 optó por suprimirlo, y la LOPJ, en su versión inicial de 1985, mantuvo idéntica supresión por considerar que los recursos existentes bastaban para corregir los defectos procesales que el incidente pretendía remediar, con lo cual sólo la Ley Orgánica 5/1997, modificada después por las Leyes Orgánicas 13/1999 y 19/2003, lo ha restablecido, y aun ello — fiel a su sentido- sólo para los estrictos supuestos de indefensión e incongruencia del fallo para los que hoy existe.

c) Muy conectado con ello, pero más cerca de nuestro propósito, debemos valorar, asimismo, lo que supone el hecho de que, cuando la Ley Orgánica 5/1997 introdujo el incidente de nulidad para los citados defectos procesales, ya su exposición de motivos indicó - precisamente porque ambos supuestos están incluidos en el artículo 24 de la CEque con esta medida se intentaba plantear "en términos más razonables la cuestión (...) de la tutela judicial ordinaria (...) de los derechos 
fundamentales", lo que significa que ya entonces se pretendió que el incidente de nulidad de actuaciones cumpliera, bien que para el ámbito mucho más acotado de la incongruencia y la indefensión, el cometido que ahora se le quiere atribuir; y, sin embargo, no consta (aunque tendría que mirar con más detenimiento las cifras) que el mismo haya probado de manera inequívoca su utilidad en tal experiencia.

d) Por lo demás, si caemos en la cuenta de que el juez llamado a resolver el incidente de nulidad de actuaciones (vid. el apartado segundo del propio artículo 241.1) es el mismo que está conociendo del caso, advertiremos las escasas esperanzas que existen de que ese juzgador cambie su criterio en este momento procesal y de que, en consecuencia, el objeto del amparo desaparezca en virtud de la resolución de dicho incidente.

e) En fin, aunque nada de lo anterior existiera, en mi criterio pesa sobre todo el dato de que la habilitación del incidente de nulidad para este cometido, tal y como lo piensa el proyecto, no agota las posibilidades procesales del recurrente ni, por lo tanto, le cierra el paso al amparo constitucional, con lo cual las demandas de amparo, aunque sea para examinarlas e inadmitirlas por carecer de contenido objetivo, van a seguir llegando el Tribunal Constitucional en un número casi idéntico al de hoy, sin ventaja alguna para el sistema y sí, en cambio, con el coste que supone el inevitable alargamiento del proceso ordinario, ahora complicado con este nuevo incidente.

En razón de todo ello, no acabo de ver, pues, como un acierto la apelación al incidente de nulidad de actuaciones que el proyecto hace. Dicho lo cual, si se me permite, concluiré mi respuesta adelantando un par de ideas sobre los términos en los que estimo que debe producirse esta traslación de parte del amparo a la justicia ordinaria, ya que con ello reafirmo mis razones frente al incidente de nulidad al tiempo que hago algunas sugerencias de las que será bueno que dispongamos desde ahora.

Primera idea: ¿Por qué desviar al juez ordinario el amparo "subjetivo" y último de todos los derechos fundamentales, como intenta hacer el proyecto con este incidente de nulidad, si sólo la discutible concepción dada por el artículo 24 de la CE al derecho a la tutela judicial efectiva es la responsable de la mala situación actual, y del acceso de los demás derechos al Tribunal Constitucional no se han derivado hasta hoy más que ventajas?

Y segunda consideración: ¿Qué sentido tiene trasladar competencias en materia de amparo a la jurisdicción ordinaria (relativas al artículo 24 o a todos los derechos amparables; ahora me da igual) si ese traslado no es pleno y el asunto puede seguir llegando al Tribunal Constitucional, aunque a éste le dotemos de instrumentos tan contundentes para inadmitir como el certiorari? En mi criterio, todo lo que no sea cortar la posibilidad de que el litigante acuda al Tribunal Constitucional tras la resolución de la justicia ordinaria, será continuar en la misma situación en la que ahora estamos. 


\section{JESÚS GONZÁLEZ PÉREZ}

1. La reforma de la jurisdicción ordinaria, estructurando realmente un proceso basado en los principios de preferencia y sumariedad, tal y como prevé el art. 53.2, CE, en el que se encontrara una rápida y eficaz protección de la tutela de los derechos fundamentales y libertades públicas, justificaría la supresión del amparo ante el TC. Pero ha de tenerse en cuenta:

a) El riesgo de la desnaturalización de esos procesos, por el abuso que, sin duda, se haría de ellos para resolver cuestiones que deben resolverse por los procesos ordinarios. Y así ocurrió con el remedo de procesos de amparo instituidos por la Ley 62/1978 de 26 de diciembre, de protección jurisdiccional de los derechos fundamentales, en especial el regulado en el ámbito judicial administrativo, dando lugar a tal número de procesos que, aparte de la incidencia que tuvieron en la tramitación de los contenciosos ordinarios, acabaron sin lograrse la celeridad pretendida y exigida por la naturaleza de algunos de los derechos lesionados, salvo cuando el derecho objeto de protección era el de reunión.

b) En todo caso, cualquiera que sea la vía procesal seguida para demandar tutela de un derecho fundamental o libertad pública, si el demandante no ha obtenido sentencia favorable, por razonable que sea, no se conforma y por lo general no renuncia a utilizar todas las vías que el Derecho arbitra, y si existe una como el amparo - por excepcional que sea-, una vez agotados los recursos judiciales, no habrá quien le convenza de que no tiene sentido interponer el amparo. Sobre todo cuando el derecho invocado es el derecho a la tutela judicial, por lesiones cometidas por un órgano judicial, por la esperanza de que, acudiendo a un Tribunal que está fuera de la organización judicial, va a lograr protección contra los desaguisados que se producen en ésta. Sobre todo teniendo en cuenta las primeras y generosas sentencias del TC. Y es que buena parte de la culpa de la afluencia de amparos, tantas veces infundados, la tiene el propio TC. Ya que aquel primer Tribunal quería dar lecciones de administrar Justicia a una Judicatura heredada del antiguo régimen, para demostrar cómo se hacía Justicia en el Estado social y democrático de Derecho: frente a la rigidez y formalismo que imperaba en los recursos judiciales se hacía gala de flexibilidad en el acceso al amparo. Acabando, como antes señalé, siendo más formalista al decidir sobre las inadmisibilidades de amparo que los Tribunales del orden contencioso-administrativo en los recursos que ante ellos se formulaban. Y es que lo que para aquellas primeras sentencias constituían flagrantes atentados al derecho a la tutela judicial en que habrían incurrido los órganos del Poder judicial, ahora han pasado a ser leves defectos que, si han ocasionado indefensión al justiciable, ha sido debido a la falta de diligencia de los justiciables o de sus abogados, por lo que en modo alguno pueden dar lugar a la nulidad de actuaciones que 
sólo conducirían a repetir procesos inútiles por prejuzgados. Muchos son los ejemplos sangrantes que podrían citarse. En la línea del formalismo se ha llegado a tales niveles que hasta el Tribunal Europeo de Derechos Humanos, pese a su prudencia, ha llegado en más de una ocasión a condenar al Estado español por estimar que sus Tribunales habían lesionado el derecho a la tutela reconocido en el Convenio de Roma, y al Tribunal Constitucional por haber confirmado las sentencias y no haber concedido el amparo.

2. El incidente de nulidad de actuaciones puede plantearse incluso después de la sentencia, como quedó claro después de las reformas de la Ley Orgánica del Poder Judicial de 1997 (L.O. 5/1997) y 1999 (L.O. 13/1999), lo que, al permitir al Tribunal subsanar los defectos de forma que hubiesen causado indefensión y la incongruencia de la sentencia, podría evitar buen número de recursos de amparo. Pero desgraciadamente, los Tribunales —como en general los órganos de cualquiera de los Poderes públicos - no son muy poco propicios para reaccionar y rectificar sus errores. Por lo que en la práctica solo en mínima parte reparan las posibles lesiones al derecho a la tutela que evitarían al justiciable acudir al amparo.

Para lo que sí ha servido el trámite, al no estar claro en qué supuestos es presupuesto y cuáles no del amparo, es para que el TC tenga otro motivo al que acudir para motivar las inadmisibilidades: si se incoó el incidente y se resolvió desestimándole, por entender que cuando se interpone el amparo ha caducado el plazo; si se acudió directamente al amparo, por estimar incumplido tal requisito previo.

\section{PABLO LUCAS MURILLO DE LA CUEVA}

Desde luego, el incidente de nulidad de actuaciones convertido en trámite previo necesario para la interposición del recurso de amparo en demanda de restablecimiento frente a la vulneración de cualquier derecho fundamental imputable al Poder Ejecutivo o los Tribunales, servirá para que el órgano judicial en el que culmina la vía de los recursos procesales tenga la oportunidad de reparar él mismo infracciones a los derechos fundamentales que, de otro modo, solamente podrían ser remediadas por el Tribunal Constitucional. En este sentido, contribuirá a disminuir el número de recursos de amparo que hoy en día se interponen. También incidirá en ese efecto el hecho de que el artículo 241.2 de la Ley Orgánica del Poder Judicial prevea la imposición de todas las costas a quien solicite la nulidad de actuaciones y vea desestimada su pretensión, además de contemplar la posibilidad de sancionar a quien promueva el incidente temerariamente con una multa de entre 90 y $600 €$.

No obstante, no creo que sean suficientes los resultados que así se logren. En realidad, el incidente de nulidad de actuaciones ha visto como progresivamente se ha ido ampliando su ámbito de aplicación en sucesivas reformas de la Ley Orgánica del Poder Judicial. Y, aunque se han centrado hasta ahora en extremar su utilidad para evitar supuestos de indefensión por defectos 
de procedimiento o por defectos internos de la resolución jurisdiccional, lo cierto es que no parece que hayan disminuido los recursos de amparo que aducen diversas formas de infracción del artículo 24 de la Constitución, sino todo lo contrario. Por otra parte, en las ocasiones en que el recurrente atribuya a una determinada interpretación o aplicación de las normas mantenida por los diferentes órganos judiciales la lesión de su derecho fundamental sustantivo, el incidente normalmente no servirá para evitar el recurso de amparo.

Tan importantes o más que la nulidad de actuaciones son otras iniciativas, de muy distinta naturaleza, que han de adoptarse para que los Tribunales de Justicia estén en condiciones de cumplir con su función constitucional de dar tutela efectiva a los derechos fundamentales y, en general, a los derechos e intereses legítimos de todos. Me refiero, por un lado, al perfeccionamiento del sistema de recursos para evitar que la única forma de combatir la vulneración de un derecho fundamental sea acudir, desde un tribunal de instancia, al Tribunal Constitucional. Luego, están las intervenciones en el plano de la organización y el funcionamiento de los órganos jurisdiccionales que, en el actual estado de cosas, poseen una gran relevancia.

Quiero decir que, sin desechar la búsqueda de reformas en las leyes procesales para afinar al máximo posible sus normas y adecuarlas a una realidad caracterizada por una litigiosidad creciente y sin abandonar los esfuerzos dirigidos a seguir aumentando el número de Jueces y Magistrados y a mejorar su formación, sobre todo, en Derecho Constitucional, me parece no menos importante la puesta en marcha de una oficina judicial configurada racionalmente para hacerla eficiente, dotada de los medios necesarios, en particular, de los que ofrecen las nuevas tecnologías, y con personal suficiente y capacitado para utilizarlos. Seguramente, los pasos decisivos que han de darse ahora son, principalmente, los que afectan a las infraestructuras de la Jurisdicción. Sin ellos, todas las modificaciones legislativas que se hagan no lograrán resolver el principal de todos los problemas: el extraordinario retraso, no igual en todos los casos, con el que se administra justicia.

No se trata, desde luego, de propugnar respuestas inmediatas a las demandas que se dirigen a los Tribunales, pues la función de juzgar debe realizarse en el marco de un proceso con todas las garantías y eso exige oir a las partes, practicar pruebas y reflexionar sobre cuál es la solución que el ordenamiento jurídico ofrece para cada concreto pleito. Todo lo cual requiere tiempo. Y también lo necesita el sistema de recursos. Ahora bien, que la precipitación esté reñida con la función jurisdiccional es una cosa y que hagan falta años para llegar a una sentencia firme es otra bien distinta. Son elocuentes, en este sentido, los datos estadísticos, actualizados a 2004, que ofrece el Consejo General del Poder Judicial: la duración media de un proceso civil excede de seis años, de los cuales casi la mitad los necesita la Sala Primera del Tribunal Supremo, y lo mismo sucede con el contencioso-administrativo, aunque aquí los retrasos se repartan, sobre todo, entre los Tribunales Superiores de Justicia y la Sala Tercera del Tribunal Supremo. Afortunadamente, las cosas son diferentes en los órdenes penal y social pero, en conjunto, la situación dista mucho de ser aceptable. 


\section{LA REFORMA PREVISTA DE LA LOTC EN MATERIA DE AMPARO}

3. ¿Las modificaciones que introduce el Proyecto de reforma de la LOTC a su juicio contienen los requisitos y procedimientos idóneos para la pretendida reducción del número de recursos de amparo a tramitar?

\section{MARC CARRILLO}

La reforma de la jurisdicción constitucional en lo que concierne al recurso de amparo, que de hecho constituye el objeto central de la misma, responde a dos criterios que considero positivos: como ya apuntaba en los apartados anteriores de la encuesta, el primero responde a la lógica de objetivar el recurso de amparo, a través del requisito de la trascendencia constitucional del objeto de la demanda. Y el segundo, a la inversión del trámite de admisión, dado que lo que hasta ahora es un juicio de inadmisibilidad de la demanda de amparo, se deberá convertir en el futuro en juicio sobre la admisión a trámite de la misma.

La introducción del requisito de la trascendencia o la especial relevancia constitucional de la demanda de amparo supone de alguna forma la incorporación a la jurisdicción constitucional española de una cierta regla de actuación jurisdiccional próxima al writ certiorari de la cultura jurídica anglosajona que se aplica en los Estados Unidos. De esta forma, el Tribunal ha de estar dispuesto para asumir una nueva forma de enjuiciar las demandas de amparo de acuerdo con un criterio que, sin perjuicio de los intereses subjetivos que naturalmente subyazcan, prime la dimensión objetiva del recurso, basada en la trascendencia o especial relevancia constitucional del caso sometido a su enjuiciamiento.

Los criterios para definir la trascendencia constitucional que la reforma de la LOTC y que deberán ser apreciados por el TC son tres: a) su importancia para la interpretación de la Constitución; b) su importancia para su aplicación o su eficacia general; y c) su importancia para determinar el alcance de los derechos fundamentales. Se trata de tres parámetros de interpretación que claramente sitúan al recurso de amparo como garantía extraordinaria (y no subsidiaria) sobre derechos fundamentales. Una garantía ante un órgano jurisdiccional, el Tribunal Constitucional, cuya función no es la que corresponde a un órgano judicial, sino la atribuida a un órgano constitucional, concebido para garantizar la supremacía normativa de la Constitución.

Este proceso de objetivación de la demanda de amparo no ha de ofrecer dudas sobre su constitucionalidad. Cabe reiterar que la Constitución no prefigura un modelo de recurso de amparo específico, basado en la tutela de intereses subjetivos ni tampoco en criterios objetivos de interés general. En este sentido, el modelo constitucional es abierto, a partir, ciertamente, de una condición previa, ya reiterada: que la tutela de los derechos y libertades, de los intereses legítimos de las personas, la han de asegurar los órganos dependientes del Poder Judicial, cuya función es ejercer la potestad jurisdiccional, juzgando y haciendo ejecutar los juzgado, de acuerdo con la Constitución y la ley. 
Ha de ser, sobre todo, en sede de la jurisdicción ordinaria donde se dilucidan los intereses subjetivos de cualquier contencioso judicial, y en especial la tutela de los derechos fundamentales que eventualmente puedan haber quedado lesionados por la acción de los poderes públicos o de los propios particulares. Por su parte, la acción jurisdiccional en defensa de la Constitución que corresponde al Tribunal Constitucional se sitúa en un ámbito distinto, en el que la tutela de los derechos fundamentales, aún siendo un ámbito que concierne a la libertad de la persona, es también un bien jurídico de interés objetivo que interesa al conjunto de la sociedad. En consecuencia, la forma y los criterios que han presidir la garantía jurisdiccional especial o, si se quiere, el plus de protección constitucional que dispensa el recurso de amparo, no quedan predeterminados en toda su integridad por la Constitución. El carácter abierto del artículo 53.2 de la CE permite concebir el recurso en los términos que prevé el Proyecto de reforma, sin que pueda derivarse un riesgo tangible de inconstitucionalidad.

El segundo pilar de la reforma consiste en la regulación del trámite de admisión del recurso en sentido inverso. El actual artículo 50 de la LOTC establece un procedimiento de inadmisión del recurso: «la Sección, por unanimidad de sus miembros, podrá acordar mediante providencia la inadmisión del recurso cuando concurra alguno de los siguientes supuestos (...).. Mientras que el Proyecto invierte los términos al establecer que: "El recurso de amparo debe ser objeto de una decisión de admisión a trámite. La Sección por unanimidad de sus miembros, acordará mediante providencia la admisión, en todo o en parte del recurso solamente cuando concurran los siguientes requisitos: a) Que la demanda cumpla lo dispuesto en los artículos 41 a 46 y 49. b) Que el contenido del recurso justifique una decisión sobre el fondo por parte del Tribunal Constitucional en razón de su especial trascendencia constitucional (...).

Este juicio de admisión formulado en positivo, ha de permitir una mayor margen de acción al Tribunal Constitucional para evaluar la trascendencia constitucional de la demanda de amparo y, a la postre, determinar o seleccionar cuáles demandas de amparo merecen ser objeto de enjuiciamiento en cuanto al fondo, en coherencia con la lógica de la objetivación de los motivos de la demanda.

Ciertamente, el carácter de la reforma supone un cambio sustancial en la política jurisdiccional del Tribunal, como jurisdicción de la libertad a la que se refería Cappelletti. El reforzamiento de la posición de la jurisdicción ordinaria en la tutela de los derechos fundamentales, comporta que la jurisdicción constitucional ha de asumir un importante reto. Y este no es otro que es el de estar dispuesta a asumir que, con el tiempo transcurrido de jurisprudencia constitucional, el número de recursos de amparo con trascendencia constitucional sobre los que deba juzgar sea - lo que parece lógico- muy reducido. En otros términos, ello significa que no ha de ser extraño que el Tribunal juzgue al año no más de una quincena de recursos de amparo. Lo cual ha de comportar un cambio notable en la cultura jurisdiccional, que permita poner en práctica un criterio de enjuiciamiento constitucional, que exige poner en práctica un rigor 
extremo en detectar la existencia de la relevancia constitucional, de acuerdo con los parámetros objetivos que la reforma aporta. Esta nueva cultura jurisdiccional ha de incidir también, claro está, en la organización interna y en los métodos de trabajo internos. Y todo ello, a través del Tribunal reunido en pleno como órgano de enjuiciamiento de la relevancia constitucional de los recursos sobre los que decida actuar.

Es evidente que, además de la dificultad que este cambio en la lógica jurisdiccional del Tribunal Constitucional pueda suponer, es preciso que para que, transcurrido el tiempo razonable, la reforma llegue a buen puerto será necesario acometer una revisión importante en la regulación actual de los procedimientos de la tutela de los derechos fundamentales por los tribunales ordinarios. Y esta revisión habría de ser paralela a la que se proyecta sobre la jurisdicción constitucional, lo cual viene a significar que aún teniendo en cuenta su importancia, resulta insuficiente la que se ha previsto con la ampliación del ámbito material de aplicación del incidente de nulidad de actuaciones.

\section{LUIS MARÍA DÍEZ-PICAZO}

Soy mucho más optimista sobre la posible efectividad de otras modificaciones contempladas en la reforma de la Ley Orgánica del Tribunal Constitucional. No me parece nada mal que sean las Secciones $-\mathrm{y}$ no las Salas, como hasta ahora- quienes conozcan de la mayor parte de los amparos. En particular si ello va acompañado de una revisión de las arriba mencionadas pautas internas de trabajo, las Secciones pueden ser la sede idónea para una tramitación y resolución expeditas de los recursos de amparo. Téngase en cuenta, además, que la mayoría de los amparos no plantean problemas nuevos, por lo que su atribución a las Secciones no pondría en peligro la unidad de la jurisprudencia constitucional.

Siempre en este orden de consideraciones, hay que hacer una observación: el hecho de que un determinado problema de derechos fundamentales esté perfectamente claro en una jurisprudencia constitucional constante no implica que dejen de producirse casos al respecto, a veces incluso con mucha frecuencia. Cualquier lector asiduo de la jurisprudencia constitucional conoce la enorme cantidad de sentencias que siguen dictándose sobre incongruencia omisiva, notificaciones por edictos, o agravación de condena en apelación sin haber oído al reo, por no citar sino algunos ejemplos. Ello significa, por desgracia, que la permeabilidad de los tribunales ordinarios a la jurisprudencia constitucional no siempre es la que sería deseable. Y, precisamente por esta razón, no es del todo convincente la idea — por lo demás, sugestiva- de reservar el recurso de amparo a resolver problemas verdaderamente novedosos en el terreno de los derechos fundamentales. También es preciso asegurar la efectiva aplicación del acervo jurisprudencial existente.

Más matizado ha de ser el juicio sobre la otra gran modificación prevista para el recurso de amparo: transformar el trámite de admisión de negativo a po- 
sitivo. En otras palabras, en vez de demostrar que no hay motivo para rechazar a limine el recurso, demostrar que hay buenas razones para entrar a conocer de él. Ciertamente, a primera vista se trata de un endurecimiento de las condiciones de admisión; pero no es seguro que, más allá de las palabras, esto suponga un cambio radical con respecto a la situación actual. Hoy en día se inadmiten ya muchos recursos de amparo por falta de importancia que justifique un pronunciamiento de fondo del Tribunal Constitucional. Aquí la cuestión no es tanto si el recurrente debe demostrar el interés de su caso, como si el Tribunal ha de justificar, aunque sea someramente, la inadmisión. A mi juicio, en la medida en que la inadmisión haya de ser motivada, cualquier reforma del trámite de admisión no resolverá el problema de la avalancha de amparos. Es verdad que un mecanismo de tipo certiorari - o sea, la discrecionalidad en la admisión- puede suscitar reservas en una cultura jurídica, como la nuestra, tan europeo-continental y a veces también tan tradicional. En todo caso, si se quiere resolver el problema por la vía de la admisión, habría que adoptar medidas mucho más radicales.

Aún con respecto a la reforma del trámite de admisión del recurso de amparo, conviene no olvidar lo que se ha dicho un poco más arriba: el recurso de amparo cumple una función de garantía de la efectividad de la jurisprudencia constitucional frente a los tribunales ordinarios, por lo que reservarlo a aquellos casos que sean verdaderamente novedosos puede conducir a la erosión del acervo jurisprudencial. ¿De qué serviría la jurisprudencia constitucional sobre notificaciones edictales, por ejemplo, si luego no cupiera recurso de amparo en los muchos casos que se siguen produciendo de notificaciones contrarias a las exigencias jurisprudencialmente establecidas?

Una última modificación prevista para el recurso de amparo que me parece auténticamente encomiable es la referida a las medidas cautelares. No sólo se prevé la posibilidad de acordar medidas cautelares distintas de la suspensión del acto impugnado, sino que se hace una regulación mucho más detallada de las condiciones de la tutela ad interim de los derechos. Así, la Ley Orgánica del Tribunal Constitucional se adapta a la modernización que en materia de medidas cautelares ha tenido lugar, por obra del legislador y de los tribunales supranacionales, en los últimos años y, en todo caso, después del año 1979 en que aquélla fue originariamente aprobada.

\section{FRANCISCO JAVIER GARCÍA ROCA}

La principal solución a la enfermedad, la elefantiasis del amparo constitucional que pone en peligro la salud del resto del cuerpo de la jurisdicción constitucional, es lo que podemos llamar "seleccionar en positivo": admitir lo importante en vez de continuar inadmitiendo pequeños asuntos donde la dimensión subjetiva no va pareja a la objetiva. Respecto del precedente alemán, Peter Häberle ha sostenido que no es algo tan discrecional como el writ of certiorary de la Corte Suprema estadounidense: el Tribunal, en teoría, no puede 
elegir, viene obligado a admitir los recursos que tengan interés o relevancia constitucional, existe un "deber de admisión". Pero me parece que tal decisión judicial responsable será en la práctica, sin duda, muy discrecional. Y quizá el Tribunal debería antes o después autolimitarse, y publicar y dar a conocer a la opinión pública, a la comunidad de los juristas, los criterios con los que anualmente piensa acometer ese juicio de admisión.

El nuevo art. 50.1.b] del Proyecto exige que el contenido del recurso "justifique una decisión sobre el fondo por parte del Tribunal Constitucional" en razón de su "especial trascendencia constitucional". Y el actor tiene como carga justificar la especial trascendencia constitucional del recurso, cualidad que se erige en un requisito de la demanda (art. 48.1). Más allá de un debate semántico y nominalista acerca de si debió mejor denominarse "relevancia" o "interés", la crítica más importante atiende a la inseguridad jurídica, entendida como incerteza acerca del juicio de admisión que una cláusula tan abierta encierra. Pero éste tampoco creo sea un verdadero problema: no menos impreciso es resolver cuándo un recurso "carece manifiestamente de contenido constitucional que justifique una decisión sobre el fondo", un motivo de inadmisión (art. 50.1.b]) que lleva aplicándose desde 1988 (y como art. 50.2.b] desde el principio) y la jurisprudencia ha descompuesto en un haz de variantes ${ }^{10}$. La "especial trascendencia constitucional" es un concepto jurídico indeterminado perfectamente delimitable a posteriori, caso a caso, mejor que en abstracto y de forma general. Y criterios da el Proyecto allí mismo para determinarlo cuales son: atender a la importancia "para la interpretación de la Constitución, para su aplicación o para su general eficacia, y para la determinación del contenido y alcance de los derechos fundamentales". No debería ser, en definitiva, problemático un juicio liminar sobre la trascendencia objetiva del caso: sobre su importancia para interpretar y garantizar los derechos fundamentales de todos. Por decirlo como haría Juan de Mairena: aquello nuevo, aquello que debe matizarse, aquello que debe corregirse en provecho de todos. Pasado un tiempo razonable, los Abogados de las partes sabrán con bastante seguridad (esa cualidad de "predecible" de una decisión de la que habla el Tribunal Europeo de Derechos Humanos) cuándo un amparo tiene visos de poder ser admitido a trámite y cuándo no.

Esta solución coincide en su mayor parte con la propuesta unánime que hizo el citado seminario de la ACE en Madrid el 2004. Y es notorio que tiene inspiración alemana, allí el alto tribunal debe admitir una queja constitucional cuando tenga un "Significado constitucional fundamental" según el art. 93a.2.a] de su Ley. Yo no tengo reparos a administrar esta medicina. Es la solución menos mala: un direct acces (como se conoce en el ámbito del Consejo de Euro-

9 Peter HÄBERLE: El Tribunal Constitucional como Tribunal ciudadano. El recurso constitucional de amparo, traducción de Joaquín BRAGE, FUNDAP, Méjico, 2005, p. 127.

10 Puede verse Ángel GÓMEZ MONTORO: "Comentario al art. 50" en Comentarios a la Ley Orgánica del Tribunal Constitucional, J. L. REQUEJO (coord.), Tribunal Constitucional-BOE, Madrid, 2001, pp. 796-833. 
pa) sin limitaciones es sencillamente incompatible con la subsistencia de una jurisdicción constitucional concentrada que fue pensada para actuar a impulsos de unos pocos sujetos constitucionales. La misma protección internacional que dispensa el Tribunal Europeo de Derechos Humanos (en adelante, TEDH) desde la reforma del Protocolo 11 en vigor sólo desde 1998, que introdujo un acceso directo, se encuentra ya colapsada y se anuncia una contrarreforma con un Protocolo 14 y diversas medidas organizativas contenidas en el interesante Informe emanado por Lord Woolf.

Quizá podría hacerse una advertencia, aprendiendo de lo acaecido en el pasado. El Proyecto de ley identifica unas providencias de inadmisión (art. 50.3) que - dice- "se limitarán a especificar el requisito incumplido". Bien es verdad que no se dice expresamente que no deberán motivarse, pero quiere decir exactamente eso. Esperemos que el principal destinatario de la reforma, con un exceso de prudencia que sería contraproducente, no devalúe la eficacia de la reforma, como hizo en 1988 al inventarse unas providencias motivadas, sin tradición alguna en nuestro ordenamiento, que la ley no contemplaba y que precisamente por eso llamó providencias.

Barrunto que la actual reforma parece estar pensada para que los doce Magistrados del Tribunal Constitucional deleguen —bajo su control— en sus muchos Letrados (quizá mediante una comisión de preadmisión presidida por un Magistrado de forma rotatoria) la rápida inadmisión de miles de amparos, y la admisión de sólo unas pocas decenas, de acuerdo con las directrices que reciban de las Salas o mejor del Pleno. De manera que los Magistrados puedan concentrase en escribir no más de medio centenar de buenas y breves sentencias de amparo al año, y reservar sus esfuerzos para poder ejercer mejor — de manera más reflexiva y estudiosa- el resto de sus competencias jurisdiccionales.

El Proyecto de ley incorpora también varias soluciones complementarias de esta principal, que tampoco veo discutibles sino cabales. Veamos algunas de estas medidas. La admisión a trámite (art. 50.2 de la reforma) se haría por providencias no motivadas de las Secciones, normalmente, o de las Salas, si hubiere mayoría pero no unanimidad. Por consiguiente, ya no sería necesario un Auto (de inadmisión normalmente, pero también puede que de admisión) tras escuchar las alegaciones del solicitante de amparo y del Ministerio Fiscal (art. 50.3 LOTC), como ahora ocurre, y se ganaría en economía de esfuerzos.

Como ya ocurre ahora, frente a las providencias de inadmisión, sólo cabría recurso de suplica por el Ministerio Fiscal en el plazo de tres días, lo que obligaría a esta institución a todavía más diligencia que la actual. Pero, sinceramente, no sé si este órgano está realmente en condiciones de cumplir esa función de airbag, de cláusula de seguridad, en tan breve plazo, pues supone muchísimo trabajo. Probablemente será un mero expediente de trámite, salvo excepciones manifiestas, como ahora acontece y quizá sea inevitable.

Se permite deferir la sentencia de amparo de las Salas a las Secciones una vez concluso el trámite de alegaciones (art. 52.2) y, en consecuencia, advertida la escasa enjundia del asunto. Pero si realmente se admiten una cincuentena de 
casos al año en los que se pretenda crear Derecho, interpretar ex novo la Constitución, resulta un poco contradictoria esta posibilidad, —isentencias de Secciones que innoven el ordenamiento? - y puede que devenga ociosa. Mala señal será si hay que usar mucho esta herramienta...

No están ligadas directamente a la reducción de la cifra de amparo las siguientes medidas que la reforma introduce y que - estimo- deben ser reseñadas por su importancia o carácter polémico. Para solventar algunas aisladas cuestiones o conflictos de jurisdicción con el Poder Judicial, en particular con las Salas Primera y Segunda del Tribunal Supremo y muy aireadas por la pren$\mathrm{sa}^{11}$, se introducen unas «anulaciones en defensa de la jurisdicción del Tribunal Constitucional" (artículos 4.3, 10.h y 92.2 del Proyecto) cuya competencia se da al Pleno. El Tribunal Constitucional podría "anular de oficio" (¿siendo a la vez juez y actor?) los "actos" (¿también los acuerdos no jurisdiccionales del Tribunal Supremo?) y "resoluciones" que "contravengan" su jurisdicción, o que no permitan que agoten sus decisiones la vía jurisdiccional interna, tras dar audiencia al Fiscal General del Estado y al órgano autor del acto o resolución. También podría declarar la nulidad de cualesquiera resoluciones que contravengan las dictadas en el ejercicio de su jurisdicción y "con ocasión de la ejecución de esta" (pueden recordarse entre otros los notorios casos "Pantoja" y "Preysler II"). Admito que no veo con claridad la idoneidad de esta herramienta que quizá sea excesiva: el remedio puede ser peor que la enfermedad. La reforma de la LOTC no detalla este nuevo y peculiar procedimiento como debería y, visto que no conozco precedentes que nos ilustren sobre su funcionamiento, me produce dudas procesales.

No es problemática, en cambio, la prohibición legal de formular juicios de valor sobre la labor de los órganos jurisdiccionales (art. 54). Se le ordena al Tribunal Constitucional que se limite a otorgar o denegar el amparo y "se abstenga de cualquier otra consideración sobre las actuaciones de los órganos jurisdiccionales". Es muy correcto: se codifica una norma no escrita que debe ser un uso habitual, una norma de la "corrección constitucional" propia de las relaciones entre órganos del Estado. Para criticar ya estamos los profesores... Pero quizá la ley correspondiente debería imponer a los órganos judiciales el mismo estándar respecto de sus inferiores.

Por último, y con origen en la reciente e improcedente condena por responsabilidad civil de los Magistrados constitucionales (al simplemente inadmitir un amparo disparatado en ejercicio de su exclusiva jurisdicción constitucional), se efectúa una muy moderada extensión de la inviolabilidad de los Magistrados del Tribunal Constitucional. No me parece discutible y no entiendo los reparos suscitados en el Informe del Consejo General del Poder Judicial. El Proyecto asevera que "no pueden ser encausados ni perseguidos por las opiniones expresadas y los votos emitidos en el ejercicio de sus funciones"

11 La desproporcionada y erróneamente denominada "Guerra de Cortes", una terminología italiana que deberíamos olvidar, porque las palabras acaban incidiendo en los hechos. 
(art. 22.2, la cursiva muestra los añadidos de la reforma). La modificación es mínima y puede perfectamente entenderse que incluso la Ley ya ofrece esta protección y que simplemente se hace ahora pedagogía explicitando mandatos para sus destinatarios: los órganos judiciales. La reforma poco añade a lo que ya estaba en la LOTC, con origen en la regulación de la Corte Costituzionale desde los años 40 y 50, y que asimismo existe en otros países europeos: una inviolabilidad al modo de los parlamentarios que no es impropia para un legislador negativo. La situación entre los Magistrados de carrera que integran el Poder Judicial y están sometidos al imperio de la ley y la de los Magistrados constitucionales es distinta, puesto que los segundos no están sometidos a la ley sino únicamente a la Constitución y a su ley orgánica (art. 1.1 LOTC) y esa es una actividad de riesgo, por su acusada politicidad y la ausencia de predeterminación normativa de sus decisiones, que demanda de especiales garantías ${ }^{12}$.

\section{ÁNGEL GARRORENA MORALES}

Aun teniendo en la mayor estima el enorme esfuerzo realizado por los autores de la reforma, no me parece que las medidas que en el proyecto se proponen vayan a reducir significativamente el número de demandas que está llegando al Tribunal Constitucional. Y aun si lo lograran (lo que es bastante dudoso, porque el proyecto no trabaja, como debiera, sobre la idea de disminuir el número de recursos que tienen abierto el camino hacia el Tribunal, sino sobre el presupuesto de permitir que éste, tras tener que estudiarlos, pueda decidir no entrar en su fondo), no considero que sean las más adecuadas para conseguirlo. Veamos por qué.

Tres son las medidas en las que el proyecto confía para renovar el recurso de amparo, aunque sólo una de ellas, la primera, constituya la clave de la reforma y las otras dos, siendo importantes, operen como meros refuerzos o coadyuvantes suyos. Esas medidas son: la modificación de la admisión a trámite a efectos de instaurar un modelo de admisión objetiva basado primordialmente en razones de este tipo y no en la estricta existencia de una lesión en nuestros derechos; la posibilidad de deferir la resolución de los recursos de amparo de las Salas a las Secciones, aumentando así la capacidad del Tribunal para sentenciar; y la habilitación del incidente de nulidad de actuaciones a fin de permitir que la justicia ordinaria tenga una oportunidad más de remediar la lesión antes de que el interesado acuda al Tribunal Constitucional.

Sobre el incidente de nulidad de actuaciones, ya he dicho en la respuesta anterior las razones por las que pienso que éste no es el instrumento más adecuado para desplazar parte de la carga que el amparo supone a la justicia ordinaria. Podemos, pues, centrarnos en las otras dos propuestas.

12 Puede verse con más detalle mi pequeño artículo: «La inviolabilidad de los Magistrados del Tribunal Constitucional" en Derecho y Jueces, El Derecho editores, año 5, n. ${ }^{\circ} 30$, enero 2006, p. 1-2. 
Por lo que respecta a la primera y principal de ellas, la objetivación del recurso de amparo o, lo que es igual, la sustitución del actual modelo basado en la necesidad de reparar la lesión subjetiva causada en los derechos del recurrente por otro modelo distinto en el que la admisión del recurso sólo se produce cuando la "especial trascendencia constitucional" del supuesto justifica la adopción de una decisión sobre el fondo a fin de que el Tribunal pueda sentar en ella criterios que trasciendan al caso concreto sobre la interpretación o la aplicación de nuestras libertades, he de comenzar por decir que, en un primer momento (allá por aquellos años en los que se empezaba a hablar de tal posibilidad entre nosotros), me pareció que ésta era una solución eficaz a la vez que muy sólida y bien fundada. Eficaz, porque efectivamente permite seleccionar los estrictos casos de los que debe ocuparse el Tribunal Constitucional. Y sólidamente fundada porque, en su trasfondo, más allá de una estrategia con la que encarar el exceso de trabajo del Tribunal, hay una atendible concepción de la justicia constitucional y de su particular cometido dentro del Estado de Derecho (definir objetivamente la constitucionalidad del sistema) que dista mucho de ser banal.

Sin embargo, con el tiempo, mi opinión ha ido cambiando y hoy estoy bastante lejos de pensar así. La principal razón de mi distancia actual con este planteamiento reside en que no logro abandonar la idea de que la concepción subjetiva del recurso de amparo es la única que se corresponde con el espíritu de la vigente Constitución española, amén de ser la que mejor sirve a la finalidad garantista de dicho instituto. Ya se que se pueden dar mil vueltas a la interpretación de la cláusula "en su caso" que enuncia el artículo 53.2 de la CE, y que algunas de las versiones admisibles de la misma podrían servir para alejar a dicha fórmula de su sentido más común (aquél próximo a la concepción subjetiva según el cual siempre ha significado: "en caso de que el amparo no baya sido suficientemente prestado antes por la justicia ordinaria") y atraerla, en consecuencia, al terreno de la concepción objetiva ( "en su caso" significaría entonces "en aquellos específicos casos en los que asi lo tenga establecido el legislador", enunciado en el que podrían tener perfecta cabida los solos supuestos de carácter objetivo). Pero no se trata de eso. Se trata de que, en el lenguaje mismo de la Constitución, la palabra "amparo" no es gratuita: apunta a hacernos pensar intuitiva y necesariamente en la protección subjetiva de nuestros derechos constitucionales. Y se trata también de ser sensibles hacia el hecho de que ese sentido, que para mí trasluce el espíritu mismo de la Constitución, ha calado además muy hondo en la propia ciudadanía española, probablemente porque (si dejamos de lado sus conocidos, pero puntuales defectos) este instituto ha funcionado para ella de una manera muy satisfactoria. Es esto lo que me hace pensar que el modelo objetivo del recurso de amparo podemos hacerlo caber — si queremos - en la Constitución, pero no es exactamente "constitucional"; del mismo modo que me lleva a preguntarme si será sensato tirar por la borda una experiencia garantizadora tan positiva y de tantos años para obtener un resultado (el desahogo del Tribunal Constitucional) que, a mi juicio, se puede alcanzar por otros medios; máxime cuando la también ne- 
cesaria dimensión objetiva del recurso (esto es, la posibilidad de que el Tribunal siente doctrina a través de sus resoluciones) no se pierde por el hecho de que el mismo opere como instrumento reparador de las lesiones subjetivas causadas en nuestros derechos fundamentales.

Junto a la anterior, existen otras reservas que oponer a la concepción objetiva del recurso de amparo, al menos tal y como la ha acabado de definir el proyecto. Para mí, tienen un peso menor si se las compara con la que acabo de exponer, pero bueno será que no las olvidemos: a) En concreto, es verdad que ninguno de los tres criterios que el artículo 50.1,b) del proyecto establece para saber cuándo existe esa "especial trascendencia constitucional" de la que va a depender la admisión del recurso (importancia del supuesto para la interpretación de la Constitución; para su aplicación o su eficacia general; o para la determinación del contenido y alcance de los derechos fundamentales) abre un portillo a la consideración de razones o intereses subjetivos, con lo cual el grado de objetivación del recurso por el que el proyecto se inclina termina resultando tan alto - tan absoluto y sin fisuras - que, desde determinado punto de vista, parece incluso excesivo para el fin que la reforma persigue. b) Lleva además razón el profesor Pedro Cruz cuando teme que la mentalidad de los propios magistrados no esté hecha a tanta objetivación y que, en consecuencia, suponga un entorpecimiento para la viabilidad misma de la reforma. c) $\mathrm{Y}$, en fin, aunque signifique reiterar ideas ya avanzadas, es claro que la utilización del certiorari permitirá al Tribunal Constitucional seleccionar aquellos casos con los que quiera quedarse, pero no impedirá que sus miembros tengan que dedicar buena parte de su tiempo a examinar todas las demandas para ver en cuál concurre y en cuál no esa especial relevancia constitucional que ahora se convierte en decisiva.

Así pues, en razón de tales argumentos, y de algunos otros que ahora omito, no me parece que la opción por la concepción objetiva del recurso de amparo nos haga ganar — sino más bien perder - en la protección de nuestros derechos fundamentales y libertades públicas. De ahí que considere que sólo si no existiera otra solución cabría pensar en esta posibilidad.

Nos queda por considerar, pues, la tercera de las medidas propuestas por el proyecto: la posibilidad de que las Salas defieran a las Secciones la resolución de los recursos de amparo (artículos 8.3, 48 y 52 a 55 del proyecto). Mi actitud ante ella es, de nuevo, de rechazo, pero también y sobre todo - lo adelanto aquí- de extrañeza.

Desde luego, de ahí mi rechazo, pesan en mí todos los argumentos que se oponen habitualmente a esta solución. De entrada, me parece que la misma enmaraña y complica con desplazamientos innecesarios de uno a otro los niveles - hasta tres - en los que el Tribunal Constitucional puede dictar sentencia, a la vez que aumenta preocupantemente con ello la presencia de aquellos niveles en los que sólo interviene una parte de los jueces constitucionales. Creo que habilita además a las Secciones para un cometido que es muy dudoso que les deba corresponder. Eleva, asimismo, a seis (dos Salas y cuatro Secciones) el número de órganos implicados en la tarea de resolver el recurso de amparo, lo que amplía en mucho el riesgo de que surja una jurisprudencia divergente 
entre ellos. Y, aunque dicho riesgo pudiera minimizarse si el Tribunal introdujera la práctica - el proyecto no lo establece- de que las Salas tan solo defieran a las Secciones los asuntos que sean de mera aplicación de doctrina, ello (aparte de las reservas que enseguida expresaré sobre esta posibilidad) no impediría que las Salas tuvieran que invertir un tiempo nada menor en resolver si efectivamente el supuesto de que se trate es de tal condición y cuál sea esa doctrina previamente consolidada a la que las Secciones deben de atenerse.

De todos modos, lo que verdaderamente me llama la atención en esta aplicación de la citada estrategia descentralizadora al proceso que nos ocupa de ahí esa extrañeza a la que me referí- es que, según yo lo entiendo, la posibilidad de deferir los amparos a las Secciones resulta frontalmente contradictoria con la opción por la objetivación del recurso que el propio proyecto hace suya y, por lo tanto, con la filosofía misma de la reforma. ¿Por qué digo esto? Pues, sencillamente, porque es ilógico e incluso paradójico mantener que el Tribunal Constitucional se deber quedar sólo con aquellos amparos que, en razón de su "especial trascendencia constitucional", sean aptos para sentar una doctrina con interés y alcance objetivos, y luego abrir el modelo a la posibilidad de que esa tarea, tan delicada y trascendente, pueda quedar deferida a las Secciones. Y no cabe contestar que dicho desplazamiento sólo se producirá en los casos de mera aplicación de doctrina, como podrían alegar quienes intentan llenar de sentido a esta previsión, porque la mera aplicación de doctrina - ahora lo podemos entender mejor - no parece que sea ni siquiera imaginable en un procedimiento en el que la clave para que el recurso sea admitido y siga su trámite es, precisamente, que tal doctrina no existe y que el Tribunal tiene que sentarla.

En síntesis, por volver sobre el enunciado de la pregunta que se me hace, no encuentro que las modificaciones que introduce el proyecto de reforma de la LOTC sean las más idóneas para alcanzar la reducción del número de recursos de amparo, aunque esté de acuerdo en que dicha reducción debe producirse.

\section{JESÚS GONZÁLEZ PÉREZ}

Creo que, como intento poner de manifiesto al contestar la primera pregunta, la única medida que puede remediar la situación insostenible de la Justicia constitucional es la eliminación del recurso de amparo ante el Tribunal Constitucional.

\section{PABLO LUCAS MURILLO DE LA CUEVA}

Sí reducirán ese número, aunque - ya lo he indicado- no creo que en magnitudes llamativas, al menos, en un primer período. Ahora bien, la combinación de las novedades que pretende introducir el legislador —redefinición 
del incidente de nulidad de actuaciones, nueva regulación que se postula del trámite de admisión y resolución de los recursos de amparo también por las Secciones- hará que se potencien los efectos de cada una.

Quiero decir que no sólo entrarán menos recursos, sino también que será más fácil —y se hará con más agilidad— resolver sobre su admisión. Así es muy notable el cambio que trae el Proyecto de Ley Orgánica: invierte el sentido del trámite de admisión, pues pasa de estar centrado en la determinación de si concurren o no las causas de inadmisión previstas, a la comprobación por la Sección de si el recurso merece ser admitido por su especial trascendencia constitucional, extremo que habrá debido justificar el recurrente. Comprobación que, si es positiva al parecer unánime de la Sección o al de la mayoría confirmada por la Sala, determina la admisión. Además, la providencia de inadmisión sólo tiene que indicar el requisito incumplido y únicamente puede recurrirla el Ministerio Fiscal. Asimismo, se descarga en las Secretarías la apreciación de los defectos formales de las demandas, con la consecuencia de la inadmisión si no son subsanados en plazo. Estas novedades, junto con la atribución a las Secciones de la competencia para, en ciertas condiciones, resolver los recursos de amparo, eliminará buena parte del trabajo que ahora ocupa al Tribunal Constitucional, de manera que, en conjunto, menos asuntos y menos trabajo, redundarán en acortamiento de los tiempos que hoy se hacen esperar sus resoluciones y más dedicación a las otras funciones que la Constitución le encomienda.

Cabe sostener, así lo hacen varias enmiendas presentadas por el Grupo Parlamentario Popular, que no es coherente centrar en la trascendencia constitucional del recurso de amparo su admisión, para luego, encomendar a las Secciones la decisión sobre el mismo. Sin embargo, no creo que haya tal contradicción, ni, desde luego, merma de la protección por esta causa. Según la nueva redacción que el Proyecto da al artículo 52.2 de la Ley Orgánica del Tribunal Constitucional, la Sala podrá deferir a la Sección la resolución del recurso una vez presentadas las alegaciones previstas en el apartado primero de ese precepto o transcurrido el plazo para hacerlas. Es decir, se trata de una facultad que puede - no está obligada a hacerlo- ejercer cuando ya dispone de todos los elementos necesarios para apreciar el alcance de un determinado recurso. En efecto, tiene ante sí, además de la demanda, las actuaciones y, en su caso, las alegaciones mencionadas. Se trata, por tanto, de un escenario diferente al que se produce en el trámite de admisión y puede suceder que en esa fase procesal posterior se aprecie ya con claridad suficiente que, por la entidad o complejidad del recurso, puede ser resuelto por la Sección, en vez de por la Sala, aplicando la doctrina sentada con anterioridad.

En estos términos, no veo problemas de incoherencia ni tampoco de menor protección. Al fin y al cabo, las Secciones también son el Tribunal Constitucional. 


\section{OTRAS PROPUESTAS DE REFORMA DEL RECURSO DE AMPARO}

4. ¿Qué otras fórmulas alternativas o complementarias, en su criterio, podrian tomarse en consideración para reformar el actual recurso de amparo?

\section{MARC CARRILLO}

De lo expresado en la anterior cuestión hay — sin duda - que deducir que además de la reforma de la jurisdicción constitucional en lo que concierne al amparo de derechos fundamentales, ya se hace precisa una reforma de la jurisdicción ordinaria como ámbito de tutela de los derechos fundamentales. Es más, del buen criterio que se tenga en relación a la revisión de los procedimientos hoy vigentes para regular el acceso a la jurisdicción, depende que la objetivación del recurso de amparo como garantía extraordinaria de derechos fundamentales pueda asentarse a medio plazo.

En consecuencia, a mi juicio son necesarias medidas complementarias a la reforma del recurso de amparo, pero que en su mayor parte no afectan a la revisión de este procedimiento constitucional sino, precisamente, a la regulación del amparo ordinario. En este sentido, cabría reflexionar sobre los siguientes aspectos a abordar en futura reforma del amparo judicial:

a) La necesidad de configurar un procedimiento único preferente y sumario del artículo 53.2 CE, de tutela de los derechos fundamentales, con independencia del orden jurisdiccional en el que la lesión del derecho se haya producido, a excepción de aquellos derechos que por su propia naturaleza requieren de un procedimiento especial (derecho al habeas corpus, derecho de reunión o algunos aspectos del derecho de sufragio). A este respecto, no parece razonable que todavía subsista la diversidad de procedimientos vigentes, configurados de acuerdo con la naturaleza de la relación jurídica de los sujetos que entran en controversia, a saber: un procedimiento especial de tutela de derechos fundamentales en la Ley de la Jurisdicción Contencioso-Administrativa; otro en el ámbito del procedimiento laboral; una Ley orgánica de Protección civil del derecho al honor, a la intimidad personal y familiar y a la propia imagen, etc.

b) La tutela de los derechos fundamentales requiere una acción diligente de los órganos de garantía jurisdiccional, que no puede admitir demoras, si el Estado de Derecho pretende ser eficiente en un ámbito en el que la calidad de la vida democrática está en juego. Esta diligencia ha de ser dispensada a través de resoluciones judiciales firmes conformes a derecho, sobre el fondo de la pretensión del ciudadano. Pero la tutela de derechos fundamentales, no sólo se garantiza a través de sentencias sino que, si procede, se inicia por medio de medidas cautelares. La justicia cautelar, integrada por un conjunto de medidas jurisdiccionales de carácter provisional, ha de ser el primer estadio de la garantía de los derechos de la persona. Por esta razón, se hace preciso 
desarrollar los diversos tipos de medidas cautelares existentes en los diversos procedimientos antes descritos, incorporando nuevas formas de tutela cautelar, en especial las de carácter positivo, o precisando el contenido de las ya existentes. En este sentido, habida cuenta del tradicional apego interpretativo del juez español a la literalidad de la ley, no sería inconveniente que el legislador procesal, en ese procedimiento único de tutela judicial de los derechos fundamentales, precisase más y mejor los tipos de medidas cautelares a tomar. En especial, las relativas a las obligaciones de hacery de no hacer, concretando el alcance de los parámetros interpretativos habituales, como el fumus boni iuris, el periculum in mora, la salvaguarda del interés general, etc.

c) En el proceso de descentralización política que ha comportado el Estado de las autonomías, es lo cierto que el Poder Judicial ha vivido muy al margen del mismo. Sin embargo, con los procesos de reforma de Estatutos de autonomía, se ha iniciado una dinámica tendente a cambiar esta lógica centralizadora. En este sentido, el reforzamiento de las atribuciones a los Tribunales Superiores de Justicia en el territorio de las Comunidades Autónomas, puede permitir, con la consiguiente reforma de la Ley Orgánica del Poder Judicial (LOPJ), que dichos tribunales puedan devenir la última instancia judicial de tutela de los derechos fundamentales. De esta forma, además de procurar una mayor proximidad territorial de la Administración de Justicia al ciudadano, podría reducirse el espacio procesal de la vía judicial previa. Un ejemplo que al respecto podría resultar funcional, a reserva de la nueva configuración que establezca la futura reforma de la LOPJ, es la prevista en el artículo 95.2 de la Propuesta de reforma del Estatuto de Autonomía de Cataluña, de próxima entrada en vigor: «El Tribunal Superior de Justicia de Cataluña es la última instancia jurisdiccional de todos los procesos iniciados en Cataluña, así como de todos los recursos que se tramiten en su ámbito territorial, sea cual fuere el derecho invocado como aplicable, de acuerdo con la Ley Orgánica del Poder Judicial y sin perjuicio de la competencia reservada al Tribunal Supremo para la unificación de doctrina. La Ley Orgánica del Poder Judicial determinará el alcance y contenido de los indicados recursos".

\section{LUIS MARÍA DÍEZ-PICAZO}

Mi opinión, expresada ya en varias ocasiones, es que las dificultades no proceden tanto del recurso de amparo, como del recurso de amparo por invocación del art. 24 de la Constitución. Examinando las estadísticas del Tribunal Constitucional, es claro que los amparos en que no se invoca dicho art. 24 representan un porcentaje muy pequeño del total. Y si se quitaran también los amparos fundados en los arts. 14 y 25 de la Constitución, el número sería francamente modesto. Esto quiere decir que el recurso de amparo como medio de 
protección de los derechos fundamentales sustantivos no supone, en modo alguno, una carga insoportable para el Tribunal Constitucional; y, precisamente por ello, no tendría sentido reducir la garantía que para esos derechos implica la posibilidad de acudir al Tribunal Constitucional por vía de amparo.

Si el verdadero problema es el art. $24-\mathrm{y}$, en menor medida, los arts. $14 \mathrm{y}$ 25-, atáquese por ahí. Es verdad que limitar el acceso al amparo sólo para algunos derechos exigiría un serio esfuerzo de técnica legislativa. Algunos, además, piensan que sería de dudosa constitucionalidad, aunque yo creo que el inciso "en su caso" del art. 53 de la Constitución deja margen al legislador orgánico para diversificar el acceso al amparo de unos derechos u otros. En todo caso, no hay que engañarse: ninguna medida será realmente efectiva si no afronta el desmesurado uso del art. 24 de la Constitución, que además es alimentado por el acentuado gusto de la propia jurisprudencia constitucional hacia los temas procesales.

Una última reflexión sobre la reforma del recurso de amparo: si ésta alcanzara su objetivo y se redujera sensiblemente el número de amparos, muy probablemente gran parte de la litigiosidad que hoy se dirige hacia el Tribunal Constitucional se reconduciría hacia otros órganos jurisdiccionales, como es muy destacadamente el Tribunal Europeo de Derechos Humanos. La experiencia enseña que los países que más asuntos proporcionan al Tribunal de Estrasburgo son aquéllos en que no existe recurso individual para la tutela de los derechos fundamentales. En otras palabras, descongestionar el Tribunal Constitucional sería, sin duda bueno, desde el punto de vista interno; pero, en definitiva, supondría desvestir a un santo para vestir a otro.

\section{FRANCISCO JAVIER GARCÍA ROCA}

A mi juicio, sería bueno ampliar el plazo para la formalización de la demanda y la presentación del recurso de amparo constitucional: el actual de 20 días hábiles (artículos 43.2 y 44.2 LOTC) se antoja especialmente breve a la vista de nuestras experiencias constitucionales y a la luz del Derecho comparado. Un plazo más largo, en torno más o menos a un mes, sería más adecuado. Un mes es el plazo que prevé la ley de Alemania. Y recuérdese que ya en la actualidad los amparos frente a decisiones y actos sin valor de ley de las Cortes Generales y los Parlamentos autonómicos (art. 42 LOTC), quizá por su mayor enjundia (lo que no es tan cierto en la realidad de los supuestos) tienen un término de tres meses para poder interponerse. La amplitud del plazo daría una mejor oportunidad a la defensa de los actores (al menos aquellos que quisieran hacerlo) para redactar mejor y motivar y fundar las demandas con mayores denuedos y, en definitiva, dotar los recursos de una mejor calidad técnica. Hay una enmienda del propio grupo parlamentario del Gobierno que propone un plazo de cuarenta días, de forma que estaríamos a tiempo de arreglarlo. Por lo demás, se trata de un plazo máximo y no mínimo, por lo que no es de esperar que se causaran a las parte especiales problemas si hubiere una especial ur- 
gencia en acudir ante el Tribunal Constitucional para impedir la lesión, reparar sus consecuencias o impetrar una medida cautelar.

La queja sobre la baja calidad — como regla general y, claro está, sin perjuicio de muchas nobles excepciones- de las demandas es habitual entre los antiguos Magistrados y Letrados del Tribunal Constitucional que por oficio albergan experiencia en la lectura de millares de recursos muchos de ellos farragosos (y en los que se mezclan en simple commixtio hechos y fundamentos de derechos), escasamente consistentes o, técnicamente inadecuados. Tampoco sería ocioso asegurarse de una especial formación de los Abogados en recursos de amparo mediante una prueba o examen, ya que acceden ante el Tribunal Constitucional sin acreditar en modo alguno su experiencia ni sus conocimientos, en evidente perjuicio del derecho fundamental a la defensa de los justiciables que defienden. El Informe de Lord Woolf insiste asimismo en la labor de formación y divulgación respecto del TEDH.

Incluso podría preverse la posibilidad de un trámite de subsanación del contenido de las demandas (bastaría con explicitarlo mediante leves retoques en el actual apartado $5 .^{\circ}$ del art. 50 LOTC o en el apartado $4 .^{\circ}$ de la reforma), según el cual aquéllas carentes de una suficiente calidad o rigor técnico pudieran devolverse para que se redactasen y estudiasen adecuadamente, corrigiéndose estas deficiencias. Se impediría de este modo que sea el propio Tribunal — como a menudo ocurre - quien redacte virtualmente la demanda cuando advierte que puede haberse lesionado un derecho de la parte actora y su defensa no acierta a precisarlo.

\section{ÁNGEL GARRORENA MORALES}

En mis respuestas anteriores, pese a manifestar mi aprecio por el concienzudo trabajo que han realizado los autores del proyecto y a compartir su intención, he expresado mi distancia con buena parte de las medidas que proponen para reformar el recurso de amparo. No obstante, entiendo que tal desacuerdo sólo tiene valor si, en su lugar, logro aportar alguna fórmula alternativa que permita alcanzar idéntico resultado con cierta ventaja. De ahí que deba intentarlo.

Mi criterio sobre esta cuestión, expuesto, pues, con todos los temores que el lector puede imaginar, es el siguiente:

Comenzaré recordando algunas ideas que ya expuse en mi respuesta anterior, pero de las que considero que es necesario partir. Creo, efectivamente, que hay que reconstruir el modelo actual del recurso de amparo. Y creo además que hay que hacerlo de manera que libere al Tribunal Constitucional de su pesada carga presente. Pero, según ya dije, no me parece que el camino para conseguirlo pase por la objetivación de dicho recurso; en primer lugar porque, a mi juicio, la Constitución española reconoce a los particulares un auténtico derecho de acceso a la jurisdicción constitucional que les permite defender ante 
ella, bien que subsidiariamente, sus derechos protegidos por el artículo 53.2, derecho que, por lo tanto, nadie le debería retirar ( "están legitimados para interponer el recurso de amparo...", dice el artículo 162.1,b, probando así que se trata de una efectiva legitimación procesal constitucionalmente atribuida a quien "invoque un interés legítimo"); y, en segundo lugar, porque, aunque esta dificultad pudiera obviarse con sólo modificar la Constitución española, no me parecería nada recomendable hacerlo para facilitar así el mejor encaje constitucional de la versión objetiva del amparo cuando, al menos para mí, resulta obvio que la protección subjetiva y subsidiaria de nuestras libertades por el Tribunal Constitucional —esa en la que el actual modelo consiste- es hoy una de las piezas mejor logradas y más eficazmente interiorizadas en la conciencia constitucional de los ciudadanos. Es verdad que existen problemas, pero un diagnóstico exacto de la situación permite saber - como de hecho sabemos - que las referidas dificultades del amparo no las causa la garantía de la mayor parte de los derechos protegidos por tal recurso sino tan solo la mala regulación dada por el artículo 24 a la tutela judicial efectiva. ¿No haríamos, pues, bien, si el problema se circunscribe a esta figura, en conservar en el Tribunal Constitucional el amparo de esos otros derechos, cuya atención no supone más que un 10 o un 15\% de la actividad del Tribunal como juez de las libertades, dejando así para ellos las cosas como están, y en centrar, en cambio, todo nuestro empeño reformador en redefinir la protección de la tutela judicial efectiva, verdadera causa de nuestros conocidos problemas?

Si lo que acabo de decir tiene sentido, podemos dar un paso más. Hagámoslo recordando que esta reconstrucción del amparo constitucional (referida ya tan sólo a la tutela judicial efectiva) pasa, para la mayoría de los autores, por trasladar dicho cometido a la jurisdicción ordinaria. Y yo estoy de acuerdo con ello. Pero no veo tan claro, en cambio, que dicha operación pueda llevarse a cabo — sin más - mediante cualquiera de las fórmulas que habitualmente se proponen para instrumentarla (creación de una Sala de amparo en el Tribunal Supremo, habilitación de Salas de amparo en los Tribunales Superiores de Justicia...) por la sencilla razón de que, en mi opinión, el problema es algo más complejo que esto y, en consecuencia, no es posible solventarlo con simples modificaciones introducidas en las leyes que regulan la competencia o la estructura del Poder judicial. Pienso que es así porque, mientras el artículo 24 siga estando en la Constitución española con su tenor actual y, a resultas de ello, siga encomendando al Tribunal Constitucional el conocimiento y amparo de la práctica totalidad de los defectos causables en un proceso bajo el manto común de la tutela judicial efectiva, ninguna ley procesal podrá retirarle al recurrente el derecho que constitucionalmente le asiste ex artículo 24 a seguir acudiendo en amparo al Tribunal Constitucional para pedirle, tras una resolución insatisfactoria recibida desde tales instancias, que intervenga en tan ingente número de supuestos. De ahí que, en mi criterio, la reforma del recurso de amparo exija la modificación de la Constitución. Hay que cambiar el artículo 24 para retraerlo a un contenido más coherente con las limitadas posibilidades del Tribunal juzgador y, sobre todo, con la condición "constitucional" o 
"no-constitucional" (esto es, "fundamental" o no) del extenso catálogo de derechos que tal precepto cobija. Si aplicamos este test con un rigor que a mí me parece imprescindible, podremos concluir que sólo el derecho "matriz" a contar con un juzgador independiente que pacifique nuestras relaciones sociales (reducido, por tanto, a los estrictos supuestos de negación del acceso a la justicia y de total indefensión) es un derecho que afecta a los "fundamentos" de nuestra convivencia y, en consecuencia, debe permanecer en el artículo 24, conservando así la protección del Tribunal Constitucional y del recurso de amparo. Todos los demás derechos que el artículo 24 premiosamente hoy menciona, son - como es obvio- derechos y, como tales, merecen una protección jurisdiccional, pero no deberían ser "derechos fundamentales" ni ser objeto del recurso de amparo; todo lo más se les podría contemplar, si es que se quiere, en otra sección del Título I para que no perdieran su condición de "derechos constitucionales" (la misma que tienen hoy, por cierto, otros derechos no menos sensibles para sus titulares), pero, en cuanto tales derechos no-fundamentales, su garantía debería quedar en plenitud en manos de la jurisdicción ordinaria.

Una vez llegados aquí, me da igual -a los efectos que ahora nos ocupan- el modelo de protección que se elija para ellos. Dada la naturaleza procesal de los mismos, yo optaría por crear un eficaz sistema de recursos con los que remediar su lesión antes que por crear nuevas Salas en el Tribunal Supremo o en los Tribunales Superiores de Justicia, y desde luego descartaría que la vía adecuada para tal fin fuera el incidente de nulidad de actuaciones. Pero este es otro tema. Lo importante es que, con esta propuesta, habremos mantenido el actual modelo de amparo en lo que hoy funciona bien y habremos vaciado el 85-90\% de la carga del Tribunal en aquello que ni siquiera debería corresponderle, permitiendo así que pueda ocuparse mejor del 10-15\% restante.

$\mathrm{Si}$, con todo y con eso, hiciera falta seguir aumentando la capacidad de trabajo del Tribunal Constitucional, nunca acudiría para ello - por las razones que ya dije- a habilitar a las Secciones. Me parecería preferible (y aun esto sólo en una situación muy extrema) hacer tres Salas de cuatro magistrados, repartiendo entre ellas los asuntos por razón de la materia, ya que esta especialización de cada Sala en un bloque concreto de libertades incrementaría su rendimiento y, sin embargo, evitaría el surgimiento, siempre incómodo, de una jurisprudencia contradictoria entre las mismas.

Por aquí van, pues, mis planteamientos. Ya sé que para llevarlos a cabo hay que acudir a la reforma de la Constitución. Pero esto a nadie debería de extrañarle. Modificar el modelo de justicia constitucional en aspectos tan sensibles como los que nos ocupan es, por definición, un problema "constitucional", y nada tiene de insólito que para resolverlo haya que actuar sobre la Constitución misma. Si, para acabar, se me permite introducir una consideración marginal, pero tal vez no del todo impertinente, diré que lo extraño (o comprensible, pero no en clave jurídica) es que en este Estado de Derecho nos estemos acostumbrando a intentar arreglar los problemas que son constitucionales acudiendo a operar desde normas distintas de la propia Constitución (reforma 
del Senado vía reforma del Reglamento de la Cámara, aunque de ese error ya hayamos salido; redefinición del Estado de las Autonomías vía reforma de los diecisiete Estatutos; reforma de la justicia constitucional vía modificación de la LOTC...). Diría, a la vista de tal experiencia, que nunca como en este tiempo y en este país se ha alabado tanto a una Constitución, y nunca como hoy se ha eludido, sin embargo, en tan alta medida, acudir a ella para resolver aquellas cuestiones que plantea nuestra vida en común y que, por lo tanto, son inequívocamente constitucionales. La reforma del Tribunal Constitucional no es ajena a esta paradoja.

\section{JESÚS GONZÁLEZ PÉREZ}

Me remito a lo ya dicho.

\section{PABLO LUCAS MURILLO DE LA CUEVA}

Desde luego, siempre está presente el ejemplo del Tribunal Supremo de los Estados Unidos y su capacidad para escoger, sin necesidad de motivación, sino solamente por la concurrencia del voto favorable de cuatro de sus nueve miembros, los asuntos de los que conoce a través del writ of certiorari. De ese modo, procura elegir aquellos casos que plantean las cuestiones que, a su entender, preocupan a la sociedad norteamericana. Lo que no es más que una forma de identificar aquellos que tienen una especial trascendencia constitucional. Hay que advertir, asimismo, que esa selección la limita al número de asuntos que considera posible resolver con su capacidad de trabajo. Esto, en términos prácticos, se traduce en que escoge anualmente en torno a un centenar de peticiones de entre las aproximadamente 8.000 que recibe.

Ciertamente, son muy diferentes las circunstancias de ese país y las nuestras e, igualmente, son distintos los sistemas jurídicos. Allí el Tribunal Supremo encabeza una compleja organización que contempla dos niveles jurisdiccionales, el federal y el estatal, que ofrece diversos remedios procesales para corregir las resoluciones que se consideren contrarias a Derecho. De ahí que el Tribunal Supremo pueda concentrarse en las que considera más importantes de entre las solicitudes de revisión de decisiones de Tribunales de segunda instancia que le llegan de los ciudadanos y sus grupos.

La idea es, por tanto, que a mayor eficacia del sistema de recursos para asegurar la corrección de las decisiones de los Tribunales, mayor margen de apreciación se deja al órgano que culmina la organización del Poder Judicial para seleccionar los asuntos de los que ha de conocer. El Proyecto de Ley Orgánica de reforma de la Ley Orgánica del Tribunal Constitucional participa en buena medida de ese criterio. Se percibe no sólo en los requisitos de procedimiento, forma y tiempo en él previstos, sino también en la reiterada asociación del recurso de amparo con la noción de especial trascendencia constitucional [ex- 
posición de motivos, artículos 48.1 y 50.1 b)]. Noción que, pese a su carácter esencialmente objetivo no es necesariamente incompatible con el propósito de evitar a una persona los graves perjuicios derivados de una actuación administrativa o judicial en vulneración de sus derechos fundamentales.

Esta precisión de la materia objeto del recurso de amparo admisible guarda relación con su carácter subsidiario y ambas cosas tienen que ver con la progresiva asunción por los Tribunales de Justicia, siguiendo precisamente la doctrina sentada por el Tribunal Constitucional y en ocasiones anticipando lo que esta después propugna, la tutela de los derechos fundamentales.

Aun con el grave defecto del retraso, es lo cierto que los Tribunales de Justicia están siendo cada vez más los custodios de esos derechos. O sea, cumplen con creciente efectividad el cometido que les ha asignado el artículo 53.2 de la Constitución. En tanto es así, puede - y debe - el Tribunal Constitucional ser dotado de una mayor capacidad para decidir sobre cuáles de los recursos que se han interpuesto va a pronunciarse. Al final, aunque los caminos y las formas no sean exactamente las mismas —el Tribunal Constitucional no encabeza el Poder Judicial - seguramente llegaremos a una solución muy parecida en el fondo a la practicada por el Tribunal Supremo de los Estados Unidos ya que los derechos fundamentales son protegidos jurisdiccionalmente a través de un único sistema de protección confiado primero y necesariamente — salvo en lo relativo a los actos sin valor de ley de las asambleas parlamentarias- a los Tribunales de Justicia y, eventual y subsidiariamente, al Tribunal Constitucional.

\section{LA REFORMA DE LA CUESTION DE INCONSTITUCIONALIDAD}

5. ¿Qué opinión le merece que se considere la posibilidad de que se personen ante el Tribunal Constitucional las partes del proceso a quo en la cuestión de inconstitucionalidad?

\section{MARC CARRILLO}

La nueva redacción propuesta para la Cuestión de inconstitucionalidad (artículos 35.2 y 37.2 de la LOTC) en lo que concierne a la posición de las partes en el proceso a quo es una lógica consecuencia de la Sentencia del Tribunal Europeo de Derechos Humanos de 23 de junio de 1993, del caso Rumasa, (Ruiz Mateos c. España). En la medida en que esta nueva previsión normativa supone la adición de unas garantías para el ciudadano, que desde el principio habían debido de ser entendidas como ineludibles, la solución adoptada por el Proyecto de reforma de la LOTC en este aspecto es positiva.

En cuanto al objeto de la reforma, es preciso indicar que la ley o la norma con fuerza de ley, no se añaden mayores precisiones. Es decir, a pesar de que la sentencia del Tribunal de Estrasburgo que impulsó la reforma de la LOTC se refería a un supuesto de ley singular, la nueva redacción del artículo 35.2 de la 
LOTC no establece diferencias, por lo que se ha de entender que la personación de las partes del proceso a quo en el procedimiento constitucional de cuestión de inconstitucionalidad, se refiere a cualquier tipo de ley o norma con este rango, con independencia que sea una ley general o una ley singular o de caso único. La reforma adopta, pues, un criterio más amplio que el que se deriva de la sentencia del TEDH, y permite que las partes del proceso a quo puedan comparecer ante el Tribunal Constitucional para que, a través del procedimiento de la Cuestión, puedan comparecer en éste a fin de aportar también su particular juicio de constitucionalidad acerca de de la ley cuestionada. Era una laguna que la reforma ha cubierto, ampliando el criterio más estricto que el Tribunal, a la luz de sentencia del TEDH estableció en sus AATC 174/1995, 339/1995, 340/1995 y 178/1996, en los que interpretaba que únicamente cabía exigir la audiencia de los que puedan resultar afectados en sus derechos e intereses legítimos en aquellos supuestos excepcionales en que el objeto de la Cuestión sean una Ley de caso único, carente de la característica de generalidad que es la corresponde a la mayoría de la leyes.

Finalmente, es preciso hacer notar que el artículo 35.2 en la redacción reformada establece que "antes de adoptar mediante auto su decisión definitiva, el órgano judicial oirá a las partes y al Ministerio Fiscal para que en el plazo común e improrrogable de 10 días puedan alegar lo que deseen sobre la pertinencia de plantear la cuestión de inconstitucionalidad, o sobre, el fondo de ésta (...)". Pues bien, esta distinción entre pertinencia y fondo de la cuestión no parece que ofrezca sustantividad suficiente para que deba ser mantenida, si se entiende que la pertinencia del planteamiento de la Cuestión no puede ser más que tributario de un problema de fondo, cual es la convicción de la que la ley aplicable al caso y de cuya validez depende la resolución de éste es inconstitucional. Por ello, cabe entender que la pertinencia acerca del planteamiento de la cuestión engloba también las razones de fondo.

\section{LUIS MARÍA DÍEZ-PICAZO}

La posibilidad de que las partes en el proceso a quo se personen y hagan alegaciones en la cuestión de inconstitucionalidad me parece muy bien. De hecho, creo que uno de los puntos débiles de nuestra cuestión de inconstitucionalidad ha sido su configuración - legal y jurisprudencial, que no necesariamente constitucional - como un proceso puramente objetivo. Esto ha determinado que la cuestión de inconstitucionalidad haya tenido escaso interés para los litigantes y, por tanto, que la presión sobre los jueces y tribunales para que la planteen haya sido ligera. Además, la actual imposibilidad de que las partes en el proceso a quo comparezcan ha supuesto que la cuestión de inconstitucionalidad no pueda ser vista como vía de protección jurisdiccional adecuada frente a las llamadas leyes autoaplicativas. Es muy ilustrativo a este respecto el caso Rumasa, en que España fue condenada por el Tribunal de Estrasburgo precisamente por no haber dado a la persona expropiada un re- 
curso jurisdiccional efectivo frente a la medida legislativa que incidía directamente sobre su patrimonio.

El acceso de las partes del proceso a quo al Tribunal Constitucional puede ser importante, además, en un sentido más general. Algunos distinguidos constitucionalistas vienen sosteniendo hace tiempo que el problema básico del Tribunal Constitucional es que, como consecuencia del excesivo número de amparos, ha descuidado su función central de ser el juez de la ley. Y añaden que la jurisdicción constitucional debería reformarse en el sentido de reforzar esa función central, lo que, por lo demás, no debería suponer una disminución de la protección de los derechos fundamentales, pues ésta debería concentrarse en el control de la ley. En otras palabras, en la medida en que las leyes sean auténticamente respetuosas de los derechos fundamentales $-\mathrm{y}$, se entiende, siempre que los tribunales ordinarios apliquen escrupulosamente esas leyes-, no debería haber muchos casos de falta de tutela de los derechos en la vía judicial y, por consiguiente, el recurso de amparo podría ser recuperar su significado subsidiario. Pues bien, esta visión del Tribunal Constitucional pasa por transformar la cuestión de inconstitucionalidad en el proceso constitucional central del sistema. Se trataría, por así decirlo, de tener un Tribunal Constitucional más a la italiana, y menos a la alemana. No sé si esta transformación es factible tras veinticinco años de funcionamiento de nuestro Tribunal Constitucional; pero es seguro que, para intentarla, habría que reducir la discrecionalidad del juez a quo, agilizar la tramitación y resolución y, desde luego, dar voz a los litigantes.

Aún con respecto a la cuestión de inconstitucionalidad, hay que mencionar la reforma prevista de la llamada autocuestión de inconstitucionalidad. Esta dejará de ser planteada ex post, para ser planteada antes de la resolución del recurso de amparo en cuyo seno surge. Esta reforma es, sin duda, acertada, ya que no tenía mucho sentido que el Tribunal hubiera de pronunciarse sobre la constitucionalidad de una norma legal que ya ha sido considerada por una de sus Salas como el origen de la vulneración de un derecho fundamental. Es mejor - tanto en términos lógicos, como para no condicionar el juicio de constitucionalidad de la ley - que la autocuestión de inconstitucionalidad siga el esquema normal.

\section{FRANCISCO JAVIER GARCÍA ROCA}

El art. 37.2 del Proyecto permite a quienes fueron partes en el procedimiento judicial, y una vez admitida a trámite la cuestión de inconstitucionalidad, que se personen en el proceso constitucional y formulen alegaciones sobre el fondo. El interrogante que me surge es si debería ser así en todo caso y no sólo respecto de las leyes singulares. El TEDH en el caso Ruiz Mateos no exigió tanto, simplemente obligó a que se permitiera esa comparecencia cuando la ley afectaba a un círculo reducido de destinatarios. Recordemos que se condenó a España por violar la igualdad de armas en los procesos al impedir a la parte ac- 
tora, que sufrió una expropiación singular y pidió el planteamiento de la cuestión, discutir la constitucionalidad de la ley en sede constitucional y contradecir a la defensa que asumía el Abogado del Estado; la defensa de su derecho de propiedad estaba indisolublemente unida a la ley. Pero se trataba de una ley singular que afectaba a un círculo muy reducido de destinatarios, y que si bien era formalmente ley —a mi juicio- no lo era materialmente. El Tribunal Constitucional ha hecho después ciertamente un entendimiento muy restrictivo de esa jurisprudencia europea, negando la personación normalmente de quienes lo han solicitado; a mi modesto entender esas decisiones pudieron y debieron ser más generosas.

De acuerdo con la teoría clásica podríamos pensar que se desvirtúa el carácter objetivo del control normativo al permitir la personación de sujetos privados en todo caso. Pero a mi no me parece tan problemático. Hay ordenamientos con una actio populari de inconstitucionalidad y en algunos países del Este de Europa ha contribuido a desmontar el legado jurídico en diversos residuos del comunismo. Y es indudable que las partes en el proceso judicial a quo pueden expresar en el órgano ad quem puntos de vista e intereses relevantes para que el Tribunal Constitucional los escuche y libremente los pondere. Me parece sobre todo una puerta que acaso debería abrirse a las partes para compensar si se entorna mucho la puerta del amparo. Dar audiencia, permitir alegar, poco daño puede causar a una jurisdicción constitucional, pues el Tribunal siempre podrá ponderar y preferir o elegir otros alegatos expresados en el mismo proceso, preservando el carácter objetivo de la cuestión.

\section{ÁNGEL GARRORENA MORALES}

Si mi recuerdo es correcto, el anteproyecto de la LOTC preveía que aquella parte que hubiera solicitado del juez ordinario en el proceso a quo el planteamiento de la cuestión de inconstitucionalidad pudiera comparecer también en el posterior proceso seguido contra la ley en el Tribunal Constitucional. Parecía una buena idea, ya que permitía que quien había suscitado en el juez la duda sobre la constitucionalidad de la ley y, por lo tanto, estaba en el origen de la cuestión planteada, pudiera seguir manteniendo también sus argumentos ante el Tribunal encargado de adoptar la resolución definitiva. Sin embargo, finalmente el legislador no apreció la bondad de esta propuesta y, en consecuencia, el vigente artículo 37.2 de la LOTC sólo otorga legitimidad para personarse en la cuestión de inconstitucionalidad a aquellos sujetos, todos ellos institucionales, que taxativamente menciona. Como es bien sabido, el Tribunal Europeo de Derechos Humanos condenó a España en su sentencia de 23 de junio de 1993 (caso Ruiz Mateos) precisamente por considerar que este precepto había impedido personarse en una cuestión de inconstitucionalidad a la parte que la había suscitado, conculcando así el derecho de audiencia que a la misma le garantiza el artículo 6.1 del Convenio Europeo para la Protección de los Derechos Humanos. El Tribunal Constitucional, no obstante, siempre ha pre- 
textado que la citada sentencia del TEDH no afecta a todo supuesto ni impone, por tanto, la audiencia de las partes en toda cuestión de inconstitucionalidad, sino tan solo en aquellos casos en los cuales - como sucede en el caso Ruiz Mateos v. España- la ley encausada fuera una ley singular, directamente referida al particular; en los demás supuestos (sin duda, los más comunes) el Tribunal ha seguido manteniendo su doctrina contraria a tal comparecencia.

A este historia, pues, intenta poner fin ahora el proyecto de reforma que nos ocupa. Su propuesta es abrir el artículo 37.2 para permitir que quienes fueron parte en el procedimiento judicial ordinario del que trae causa la cuestión de inconstitucionalidad puedan personarse también ante el Tribunal Constitucional durante la tramitación de la misma. De progresar dicha iniciativa, la doble singularidad de la nueva regulación sería, por un lado, que ahora esa audiencia no se reduciría tan solo a la parte que hubiera suscitado la cuestión, como propuso en su día el anteproyecto de la LOTC, sino que se extendería a todas las partes, lo que es de todo punto acertado; y, por otro lado, que esta posibilidad no operaría tan solo cuando se tratase de una ley singular - como hasta hoy sostiene la doctrina oficial del Tribunal Constitucional- sino que estaría abierta respecto de toda ley, singular o no, objeto de una cuestión de inconstitucionalidad.

En mi opinión, ambas decisiones son francamente plausibles y no es de esperar que encuentren la oposición de nadie. Con ellas se hace justicia a la desairada posición de los particulares en aquellos procesos en los que se enjuicia la constitucionalidad de una ley, y se compensa en cierta medida la ausencia del "amparo frente a leyes" en nuestro sistema de justicia constitucional. A fin de cuentas, por esta vía el particular podrá tener la oportunidad de acceder al procedimiento en el que se decide la suerte de esa concreta ley que afecta a sus derechos, las más de las veces sin ser una ley singular.

\section{JESÚS GONZÁLEZ PÉREZ}

1. Siempre que se plantee ante el Tribunal Constitucional la inconstitucionalidad de una norma con rango de ley, debe darse oportunidad de que puedan personarse en el proceso no solo los titulares de derechos subjetivos que puedan derivarse de la sentencia, sino los que ostenten un interés directo. A cuyo efecto se dará la debida publicidad en los Diarios oficiales a la incoación del procedimiento, bien sea por la interposición del recurso o por planteamiento de la cuestión por un órgano judicial.

2. Por tanto, la reforma que se propone con la modificación del art. 37, LOTC, la estimo insuficiente por referirse únicamente a la cuestión planteada por órganos judiciales — no a los "recursos de inconstitucionalidad-y limitar la posibilidad de personación a quienes sean parte en el procedimiento judicial. 


\section{PABLO LUCAS MURILLO DE LA CUEVA}

Me parece acertado que se prevea, no sólo porque así se sigue el criterio sentado por la Sentencia del Tribunal Europeo de Derechos Humanos de 23 de junio de 1993, tal como recuerda la exposición de motivos del Proyecto de Ley Orgánica, sino también porque de ese modo se concilia la dimensión objetiva y abstracta del control de constitucionalidad de las normas con fuerza de Ley con los derechos e intereses de las partes que intervienen en el proceso en el que se ha planteado incidentalmente la cuestión de inconstitucionalidad. Derechos e intereses que pueden verse directamente afectados, sobre todo, por las llamadas leyes singulares. Por eso, esta novedad es coherente con la preocupación reflejada en la Constitución de evitar toda indefensión en el marco del proceso, preocupación que debe extenderse a los que conoce el Tribunal Constitucional.

\section{LOS EFECTOS TEMPORALES DE LAS SENTENCIAS DE INCONSTITUCIONALIDAD}

6. ¿Está conforme con la regulación propuesta de los efectos temporales de las sentencias de inconstitucionalidad?

\section{MARC CARRILLO}

Objetivamente, la nueva redacción propuesta en la reforma del artículo 39.1 de la LOTC es positiva y, de hecho, regulariza una práctica que en parte ya se había puesto de manifiesto en la actuación del Tribunal, por ejemplo, en los procesos relativos a las controversias competenciales, consistente en romper el binomio integrado por la inconstitucionalidad más la nulidad de la disposición objeto de juicio de constitucionalidad, a fin de preservar bienes jurídicos tutelados por la Constitución, a través de sentencias de efectos meramente declarativos, en especial en aquellas que se refieren a cuestiones de orden económico-prestacional y también, en algún caso, mediante sentencias cuyo fallo ha consistido en diferir la nulidad, instando al legislador a subsanar los vicios de inconstitucionalidad contenidos en la disposición objeto del recurso en el inmediato futuro, pero sin precisar el plazo.

Los términos con los que se expresa el texto de la reforma van, efectivamente, en esta dirección. En efecto, después de mantener el principio general por el que la sentencia que declare la inconstitucionalidad, asimismo declarará igualmente la nulidad de los preceptos impugnados o cuestionados o cuestionados, añade que «(...) No obstante, motivadamente y para preservar los valores e intereses que la Constitución tutela, la sentencia podrá declarar únicamente la inconstitucionalidad o diferir los efectos de la nulidad por un plazo que en ningún caso será superior a tres años". 
Las sentencias declarativas de inconstitucionalidad pero que no llevan anudada la nulidad del precepto de la disposición impugnada, encuentran un referente en la STC 13/1992, tantas veces reiterada, que declaró inconstitucionales determinadas partidas de la Leyes de Presupuestos para 1988 y 1989 sin proceder a su anulación, argumentando que de haberse acordado ésta se generarían graves perjuicios y perturbaciones a los intereses generales, afectando a situaciones jurídicas que ya habían quedado consolidadas, y particularmente en la política económica y financiera del Estado. Ésta es, pues, una buena razón para que la reforma de la LOTC incorpore esta excepción a los efectos de las sentencias del Tribunal Constitucional basados en la dualidad inconstitucionalidad y nulidad.

La incorporación de la modalidad de la declaración de inconstitucionalidad con nulidad diferida en el tiempo es también, en sí mismo positiva. No obstante, el plazo de tres años que propone la reforma de la LOTC al legislador a fin de que subsane el vicio de inconstitucionalidad es excesivo. La sentencia con finalidad cautelar, que prefiere mantener en el seno de ordenamiento jurídico una disposición cuyo contenido plantea problemas de adecuación a la Constitución, no puede tolerar una plazo de interinidad tan prolongado. Si bien es plausible que circunstancialmente sea preferible mantener vigente la norma, frente a la declaración inmediata de nulidad, al objeto de preservar bienes jurídicos de un determinado orden, parece necesario que ante ello el legislador responda con la máxima diligencia. Y este plazo no lo facilita. No hay que olvidar que tres años es casi la duración de una legislatura y que, si en ese lapso temporal, se producen elecciones legislativas y además cambia la mayoría de gobierno, puede ser más que probable que, incluso, el plazo no pueda ser respetado por el nuevo legislador resultante de la convocatoria electoral.

Finalmente, otro aspecto relevante de la reforma en lo que concierne a los efectos de las sentencias del Tribunal Constitucional es el referido a contenido del nuevo apartado 3 del artículo 39, que establece lo que sigue: «(...) Cuando la sentencia declare la inconstitucionalidad por insuficiencia normativa podrá conceder un plazo al legislador para que actúe en consecuencia. Si éste incumpliera dicho mandato, el Tribunal Constitucional resolverá lo que proceda para subsanar la insuficiencia".

Esta causa de inconstitucionalidad con nulidad aparentemente diferida (..., el Tribunal Constitucional resolverá lo que proceda para subsanar la insuficiencia) puede asimilarse a situación específica de inconstitucionalidad por omisión. Aunque, es difícil concluir que a partir de este nuevo precepto la reforma establezca un procedimiento autónomo con aquél sentido. En realidad, también aquí, se pueden encontrar antecedentes en la jurisprudencia constitucional que cercena el automatismo en la aplicación de binomio inconstitucionalidad y nulidad. Así, la STC 45/1989, ya declaró que la conexión entre ambos efectos no es siempre necesaria, porque «(...) la conexión entre inconstitucionalidad y nulidad quiebra, entre otros casos, en aquellos en los que la razón de la inconstitucionalidad del precepto reside, no en determinación textual alguna de éste, sino en su omisión". En consecuencia, cuando la vulneración de la 
Constitución sea imputable a una omisión legislativa, será factible adoptar una decisión de mera inconstitucionalidad. Pues bien, que ello se incorpore al texto de la reforma constituye una lógica consecuencia.

\section{LUIS MARÍA DÍEZ-PICAZO}

Estoy totalmente de acuerdo con la regulación propuesta de los efectos temporales de las sentencias de inconstitucionalidad. Es cierto que, normalmente, éstas deberán seguir produciendo efectos anulatorios ex tunc. Pero la experiencia enseña que hay supuestos en que esta eficacia normal puede ser gravemente perjudicial para el interés público o, incluso, para el correcto funcionamiento del Estado. La máxima fiat iustitia, perat mundus nunca ha sido buena consejera. A veces lo razonable es disociar inconstitucionalidad y nulidad: porque sólo es posible la anulación pro futuro, porque es preciso dar un plazo al legislador para corregir la regulación correspondiente, etc. Es bueno, por ello, que la Ley Orgánica del Tribunal Constitucional lo prevea expresamente.

Para tranquilizar a los puristas, conviene añadir que la identificación entre inconstitucionalidad - $-\mathrm{y}$, más en general, invalidez de actos de derecho públi$\mathrm{CO}$ - y eficacia anulatoria ex tunc nunca ha estado expresamente establecida en precepto alguno. Se trata de una tradición doctrinal y, en este sentido, no tendría más fundamento que el meramente consuetudinario. Por ello, es perfectamente legítimo que la Ley Orgánica del Tribunal Constitucional introduzca razonables excepciones a esa regla general de origen consuetudinario.

\section{FRANCISCO JAVIER GARCÍA ROCA}

El nuevo art. 39.1 del Proyecto establece, tanto para los recursos como para las cuestiones, que cuando la sentencia declare la inconstitucionalidad declarará igualmente la nulidad de los preceptos impugnados o cuestionados. No obstante, — se dice - que, de forma motivada y para preservar valores e intereses constitucionales, la sentencia podrá bien declarar únicamente la inconstitucionalidad, bien "diferir los efectos de la nulidad por un plazo que en ningún caso será superior a un año". mativo:

Se identifican pues tres tipos de efectos de las sentencias de control nor-

- sentencias de inconstitucionalidad con sanción de nulidad;

- de pura inconstitucionalidad y sin nulidad;

- de nulidad diferida, pro futuro o prospectiva — según prefiera llamarse- mediante el señalamiento de una dead line al legislador.

Técnicamente no es nuevo sino bien conocido, y en parte ya ha sido experimentado en los conflictos legislativos de competencia que se tramitan 
como recursos y en los conflictos positivos ${ }^{13}$. La nueva regulación me parece moderna y correcta. La reforma legal le da al Tribunal unas herramientas que en parte éste se había autoatribuido en los conflictos constitucionales ante las necesidades que los supuestos de hecho mostraban; la necesidad es siempre fuente del Derecho; pero es bueno que se codifique, regule y mejore, para que el Derecho Procesal Constitucional limite a este órgano supremo.

En particular la "nulidad diferida" es una técnica que existe en Austria desde hace tiempo con el fin de impedir los daños que especialmente en ciertos casos produce el vacío normativo, y preservar la no menos constitucional seguridad jurídica. El Tribunal puede allí dejar en vigor una norma declarada inconstitucional durante un año y medio. En unas jornadas de tribunales constitucionales centroeuropeos celebradas en Zakopane (Polonia) y a las que asistí como experto de la Comisión de Venecia del Consejo de Europa recuerdo haber preguntado por la experiencia en esta técnica al Presidente del tribunal constitucional decano de los europeos quien hizo una valoración positiva de la misma ${ }^{14}$.

Y se antoja mejor el plazo de un año que adopta el Proyecto que el de tres años, excesivamente largo, que sugiere alguna enmienda, porque conviene que el legislador se sienta conminado a reparar la inconstitucionalidad cuanto antes mediante una nueva normativa acorde con la Constitución, y, dejar transcurrir el tiempo, puede correr en el sentido de una cierta pasividad o indiferencia.

Nuestro Tribunal Constitucional por lo demás - como he dicho- ha ensayado fórmulas parecidas en las controversias competenciales. Creo recordar que la primera ocasión fue el conocido caso de las marismas de Santoña y Noja (STC 195/1998) donde el reconocimiento de la competencia autonómica para declarar una zona protegida o de reserva natural no llevó a la declaración de nulidad de la ley estatal hasta que — se dijo— la Comunidad no aprobara una ley similar con el fin de no desproteger el interés medioambiental, generando daños irreparables.

En referencia a la inconstitucionalidad sosteniendo la "incompatibilidad" sin nulidad también el BVfergG alberga larga experiencia en este sentido y no sólo el nuestro y es un asunto de sobras estudiado ${ }^{15}$.

\section{ÁNGEL GARRORENA MORALES}

La modificación de los apartados 1 y 3 del artículo 39 de la LOTC viene impuesta por la necesidad de acomodar tales preceptos a la práctica abierta por el propio Tribunal Constitucional, primero en su STC 45/1989, en la cual introdu-

13 Pueden verse mis dos estudios sobre el contenido de la sentencia de conflicto "Comentario al art. 66" en Comentarios a la Ley Orgánica del Tribunal Constitucional, ob. cit., pp. 1063-1085, y "Una teoría de la sentencia en el conflicto constitucional entre entes territoriales" allí citado.

14 Heinz SCHÄFFER la considera una técnica en ocasiones "imprescindible" en su trabajo "La relación entre el Tribunal Constitucional y el legislador (Austria), en Eliseo Aja (editor): Las tensiones entre el Tribunal Constitucional y el legislador en la Europa actual, Ariel, Barcelona, 1998, p. 38

15 Puede verse Albrecht WEBER: "Alemania" en Las tensiones entre el Tribunal Constitucional y el legislador en la Europa actual, ob.cit. p. 77-80. 
jo la posibilidad de pronunciar sentencias de inconstitucionalidad sin nulidad, y después por las SSTC 195/1998 y 208 y 235/1999, a partir de las cuales ha empezado a emitir sentencias de inconstitucionalidad aplazada. Desde este ángulo, la propuesta que hace el proyecto es correcta.

No comparto de una manera tan plena, en cambio, la forma y el alcance de esa propuesta o, si de este modo se entiende mejor, la cierta naturalidad con la que el proyecto acoge a tales tipos de sentencias. Influye en ello, sin duda, mi personal propensión a seguir pensando (como en los inicios de mi formación jurídica, aunque ahora lo haga con muchos más matices) que lo que es nulo no debe producir ningún efecto, y que el derecho que es contrario a ese otro derecho superior que es la Constitución no debería permanecer dentro del ordenamiento jurídico ni seguir rigiendo nuestra vida, porque esa vigencia suya es, a fin de cuentas, invigencia de la norma constitucional.

Mi postura, de todos modos, no es tan rígida que no entienda $-\mathrm{y}$ admita, convencido- que, en determinadas situaciones difícil o complicadamente reversibles, la pureza de este planteamiento debe ceder. Es lógico que sea así cuando, de no aceptar tal cesación del rigor exigible, se siga un daño gravoso o imposible de soportar para la comunidad, o cuando la propia estructura de la norma no permita ir más allá en la causación de la nulidad debida. Por eso me parece bien que el texto del artículo 39.1 del proyecto puntualice y advierta que esta alteración en la normal eficacia de las sentencias de inconstitucionalidad sólo podrá producirse "motivadamente y para preservar los intereses que la Constitución tutela.. Plantear el tema así equivale a enfocar esta cesación de la nulidad de una ley declarada inconstitucional como un razonable conflicto entre bienes constitucionales, lo que, en principio y a salvo lo que enseguida diré sobre otros aspectos del precepto, permite alejar la sospecha de que, con ello, estemos ante una impensable cancelación de la vigencia de la norma constitucional.

Hubiera preferido, sin embargo, que el proyecto hubiera extremado más sus exigencias, acto seguido, a la hora de atenerse a esa condición inequívocamente excepcional de tales pronunciamientos que él mismo acaba de sentar. Digo esto porque el proyecto parte de la premisa que dejo indicada, pero enseguida transmite una sensación de normalidad, de previsión opcional y admitida - a la postre, un tipo más de sentencias de inconstitucionalidad entre las posibles - que, de progresar, podría contribuir a extender la injustificada creencia de que la intención del legislador al introducir esta nueva norma dentro de la LOTC es habilitar al Tribunal Constitucional para que decida, con absoluta libertad, sobre el alcance y los efectos de la inconstitucionalidad que pronuncia, convertidos así en disponibles para él, lo cual es ya algo distinto. De hecho, de ahí a aceptar — como, en buena medida, comienza hoy a hacerseque el nexo entre inconstitucionalidad y nulidad está roto de manera incondicionada y definitiva, no hay más que un paso. Y, en mi sentir, ese es un paso que la reforma no debería colaborar a que se de.

Aparte de ello, tengo alguna otra censura que hacer al proyecto en este punto. Me refiero a la deficiente técnica con la que, a mi juicio, su texto realiza 
la identificación de los supuestos de inconstitucionalidad sin nulidad que regula. Por ejemplo, no es fácil saber si la inconstitucionalidad por insuficiencia normativa" a la que se refiere el párrafo 3 está incluida o no dentro de los dos supuestos mencionados por el párrafo 1, de la misma forma que su separación en dos preceptos distintos, con precisiones técnicas no unificadas sobre plazo concedible al legislador y sobre medidas subsidiarias, podría crear alguna incertidumbre en el momento de su aplicación. Y, en otro orden de cosas, me parece que sería oportuno reconsiderar, asimismo, la generosidad con la que el proyecto concibe el plazo otorgable al legislador para que subsane la inconstitucionalidad apreciada en la ley. Tres años es un tiempo excesivo para mantener en el ordenamiento jurídico una norma inconstitucional y, sin embargo, vigente. Con todas las dificultades que le reconozco a la fórmula que paso a proponer, y aun admitiendo que su aceptación pudiera encontrar legítimas resistencias nacidas del principio de autonomía de las Cámaras, yo hubiera preferido incluir en su artículo 39 una cláusula que dijera, con una u otra formulación, algo así como que "cuando el Tribunal declare la inconstitucionalidad sin nulidad de una norma, vinculará en su sentencia al órgano que tenga la competencia normativa a que inicie de forma inmediata, sobre proyecto del Gobierno correspondiente, en su caso, el procedimiento que permita su sustitución". Tras ello, hubiera indicado que un plazo puesto al legislador debe de existir y que le corresponde al Tribunal Constitucional establecerlo con criterios muy estrictos, pero no hubiera fijado en la norma su límite máximo porque eso puede ser una invitación a contar con dicho techo - generoso en la previsión del proyecto- aun cuando tal amplitud de margen no se necesite.

\section{JESÚS GONZÁLEZ PÉREZ}

Considero peligrosas las limitaciones temporales de los efectos del proceso que se proponen con la reforma del art. 39, LOTC, que solo serían admisibles en casos realmente excepcionales.

\section{PABLO LUCAS MURILLO DE LA CUEVA}

La preocupación por las consecuencias que comporta la declaración de nulidad de las normas legales, en particular, por el vacío que produce en el ordenamiento jurídico no es nueva. Está presente en la doctrina y en la jurisprudencia comparadas desde hace muchos años. El Proyecto de Ley Orgánica viene a recogerla y a darle respuesta en la nueva redacción que propone del artículo 39, al permitir al Tribunal Constitucional declarar solamente la inconstitucionalidad de una norma legal o declarar también su nulidad. Y, en este último caso, le ofrece la posibilidad de diferir los efectos de esa nulidad hasta por tres años. Asimismo, contempla el supuesto de que la declaración de inconstitucionalidad obedezca a insuficiencia normativa y, en tal hipótesis, le faculta 
para emplazar al legislador a actuar en consecuencia con la advertencia de que, de no hacerlo, el Tribunal resolverá lo que proceda para subsanar esa insuficiencia.

Al margen de que, en ocasiones, será bastante la declaración de inconstitucionalidad para asegurar la supremacía de la Constitución, es cierto que la declaración de nulidad de toda o de parte de una Ley produce un vacío normativo y que habrá casos en que genere problemas particularmente complejos. Sin necesidad de acudir a experiencias ajenas, hemos podido contemplar como nuestro Tribunal Constitucional, siguiendo el ejemplo de otros Tribunales Constitucionales y, precisamente, para salvar las dificultades derivadas de la expulsión de una norma legal del ordenamiento jurídico, ha buscado formas de pronunciamiento muy matizadas, dando lugar a una variada tipología e, incluso, ha habido veces en que se ha considerado obligado a precisar cuáles son los efectos de sus sentencias. Por eso, estoy conforme con las novedades que el Proyecto aporta. Del mismo se desprende que la regla es que a la declaración de inconstitucionalidad acompañe la de nulidad. Las excepciones son que el Tribunal Constitucional, motivadamente y para preservar valores e intereses que la Constitución tutela pueda limitarse al primer pronunciamiento o, incluyendo, también, el de nulidad, diferir su eficacia por no más de tres años.

Conceder un plazo al legislador para que, cuando sea preciso preservar valores e intereses constitucionales, pueda sustituir las normas inconstitucionales y hacer frente a las consecuencias derivadas de su nulidad es una solución razonable y respetuosa con el cometido del propio Tribunal. Asegurar la supremacía de la Constitución es defenderla en su totalidad, lo que implica, cuando aparecen exigencias constitucionales en contraste, buscar el punto de equilibrio entre ellas. Las innovaciones que quiere introducir en este ámbito el Proyecto sirven a ese objetivo de preservar el ordenamiento constitucional en su conjunto.

Por otra parte, hay que advertir que el régimen de los efectos temporales recogido por el Proyecto no sólo es aplicable a las Sentencias dictadas en recursos de inconstitucionalidad. También puede serlo a las que resuelvan una cuestión de inconstitucionalidad. Me parece que el eventual uso de esas facultades excepcionales por el Tribunal Constitucional en esta última hipótesis, no significa que no pueda resolverse el proceso antes de que transcurra el plazo fijado por aquél. Lo digo porque considero que la declaración de inconstitucionalidad de una norma legal es suficiente para que el Juez o Tribunal prescinda de ella a la hora de dictar Sentencia. No obstante, convendría precisar este extremo para despejar posibles dudas a este respecto y a otros estrechamente relacionados con la aplicación judicial de la Ley declarada inconstitucional y nula hasta el momento en que gane eficacia la declaración de nulidad.

Y, también, acortar la duración del período durante el que se puede diferir la eficacia de la declaración de nulidad. Tal vez sean excesivos los tres años que contempla el Proyecto de Ley Orgánica. Precisamente, porque se trata de una norma que ha sido declarada inconstitucional y, por eso, nula, no debe concederse un margen tan amplio a su autor para que la sustituya. Aunque los tres 
años solamente sean un máximo que el Tribunal Constitucional no está obligado a conceder en todos los casos. En las condiciones presentes del trabajo parlamentario, por no hablar de las que se dan en la actuación del Gobierno, basta con mucho menos tiempo. Por ello, me parece más adecuado reducir la duración máxima de ese período a no más de un año, tal como defiende una de las enmiendas del Grupo Parlamentario Popular.

\section{LA DESCONCENTRACION DE COMPETENCIAS EN EL TRIBUNAL CONSTITUCIONAL}

7. Por último ¿Cómo ve la posibilidad de atribuir a las Salas competencias hasta ahora reservadas al Pleno, por ejemplo, en la resolución de recursos y cuestiones de inconstitucionalidad o de conflictos de competencias?

\section{MARC CARRILLO}

Uno de los objetivos de la reforma de la LOTC es la de producir un proceso de desconcentración del Tribunal para mejorar su eficacia jurisdiccional, a través de una nueva distribución de competencias en su seno, dando mayor relieve jurisdiccional a las Salas en el control de la ley y a las Secciones, en el recurso de amparo.

Sin embargo, si hay acuerdo en considerar que los problemas estructurales de Tribunal Constitucional residen en el colapso que ha generado la acumulación de recursos de amparo al año (por ejemplo, 9.476 presentados en 2005), una situación que, de hecho, le impide ejercer adecuadamente sus funciones constitucionales, parece obvio que el problema está en este procedimiento y no en otros. Y que resolviéndolo, el ejercicio pleno de las otras competencias del Tribunal, es decir, las relativas al control de la ley, debería quedar desbrozado. Por esta razón, la desconcentración propuesta sólo puede tener sentido en un período transitorio, mientras que el amparo deje de ser un problema estructural, porque el enjuiciamiento de la ley sólo debería ser atribución del Tribunal reunido en Pleno. Bien es verdad, que la previsión que establece la propuesta de reforma, es la de delegar a la Salas los recursos que puedan ser resueltos con la mera aplicación de la doctrina constitucional establecida previamente por el Pleno. Ello puede resultar funcional para los objetivos de la reforma, siempre que al respecto exista acuerdo en el Pleno. De lo contrario, de poco puede servir.

Para abordar esta última cuestión sobre la desconcentración, quizás sería también de interés añadir también en la respuesta alguna consideración acerca de la previsión que la reforma de la LOTC establece, en materia de recurso de amparo de traspasar competencias a las Secciones, en algunos casos (artículo 48).

Se trata de una posibilidad que únicamente puede tener sentido como solución transitoria, hacia otra que habría de ser definitiva y que atribuya exclusivamente al pleno del Tribunal la competencia para resolver sobre los re- 
cursos de amparo que decida enjuiciar. Es decir, si la lógica de la objetivación del recurso de amparo, basada en la trascendencia constitucional de su objeto o $-\mathrm{si}$ quiere- de la relevancia doctrinal del caso que es sometido a su consideración, conlleva que el Tribunal Constitucional aborde un muy reducido número de recursos al año, es evidente que ha de ser el Tribunal reunido en Pleno y sólo él, el que deba abordar dichos casos. Ha de ser el colegio integrado por los doce magistrados el único órgano habilitado para resolver sobre la trascendencia del caso. Más todavía, es en la deliberación y la resolución tomada por el Pleno —la única instancia constitucionalmente adecuada - donde se debe establecer la doctrina sobre los casos que presenten relevancia constitucional.

Claro es que, ésta ha de ser la situación de hecho que ha de producirse una vez que, la jurisdicción ordinaria opere como auténtica sede natural de tutela de los derechos fundamentales, y el Tribunal como jurisdicción extraordinaria. Luego, sólo en un período transitorio, a fin de descargar al Tribunal de la sobredosis de recursos de amparo acumulados, puede tener sentido que las Secciones puedan resolver también determinados recursos de amparo.

\section{LUIS MARÍA DÍEZ-PICAZO}

No me parece mal desconcentrar parte del trabajo en las Salas. Es probable que sirva para agilizar la tramitación y resolución de los asuntos. En la medida en que el Pleno puede avocar el conocimiento de los mismos, no debería haber riesgo de ruptura de la unidad de la jurisprudencia.

\section{FRANCISCO JAVIER GARCÍA ROCA}

No estoy seguro. Creo más bien que éstas son competencias "principales", funciones definitorias de la institución, que debería seguir asumiendo el Pleno. Con mayor razón, si se va a descargar al Tribunal de un importante número de amparos. El riesgo principal está en la creación de contradicciones en la jurisprudencia entre las Salas y el Pleno y además a tres bandas.

El Proyecto prevé la posibilidad de "deferir" (dar parte a otro de la jurisdicción o poder) asuntos propios del Pleno a las Salas (art. 10.1). Así los recursos de inconstitucionalidad si son "de mera aplicación de doctrina" (letra b] sensu contrario) y señalando "la doctrina constitucional de aplicación". También las cuestiones de inconstitucionalidad — se dice- "según un turno objetivo" (letra c]), pero curiosamente aquí no se establecen esas mismas garantías que para los recursos, que deberían extenderse por analogía. Respecto de los conflictos de competencia, las impugnaciones del Título V LOTC y los conflictos locales (letras d], e] y f] en relación con el apartado $2^{\circ}$ ) cabe también deferirlos "en trámite de admisión", obsérvese que en los demás asuntos no se dice en qué momento, entiendo pues que se podría hacer en cualquiera. En definitiva, la regulación legal podría mejorarse para aclararse. 
No obstante, nuestra historia no es la de un Tribunal Constitucional gemelo o mellizo (Zwillingsgericht) como el alemán, formado por dos Salas o Senados con un reparto de competencias perfecto, pero donde la ley permite apartarse de la regla general por la sobrecarga de trabajo, lo que ha planteado problemas de falta de congruencia en la doctrina de las Salas en materia de derechos. Nuestra tradición constitucional es, en cambio, la de un Pleno y dos Salas de amparo y no veo razones para modificarlo. Pero si quiere hacerse, quizá no debería intentarse como excepción a la regla, es decir, otorgando la competencia del Pleno más la posibilidad de deferir.

Desde una perspectiva práctica, si el asunto es de mera aplicación de doctrina puede bastar - y resulta muy simple - con hacer una muy breve sentencia de Pleno con fundamentación por reenvío y se evitan todos los problemas de contradicciones.

En definitiva, la regulación legal podría mejorarse y aclararse, si se opta por permitir deferir a las Salas estas competencias tradicionales del Pleno, pero, cerrado el desbordamiento del amparo, yo casi preferiría no hacerlo para evitar el riesgo de contradicciones.

\section{ÁNGEL GARRORENA MORALES}

Ya en las respuestas tercera y cuarta he dejado constancia de mi opinión contraria a la posibilidad de que las Salas desplacen la resolución del recurso de amparo a las Secciones. Ahora debo expresar mi criterio sobre las previsiones que en el proyecto de reforma trasladan —o permiten trasladar- competencias del Pleno a las Salas. Me parece que ambas cuestiones se pueden englobar en un planteamiento común porque, en el fondo, responden a una misma estrategia de descentralizaciones sucesivas y encadenadas que así lo permite. Eso es, pues, lo que hago a continuación.

En síntesis, diré que no comparto el uso que los autores del proyecto hacen de esta medida. Más aún, creo que no era preciso alterar la estructura del Tribunal Constitucional para resolver sus problemas, y menos todavía hacerlo en los términos en los que el proyecto lo hace. Estaba bien en el texto vigente que el Pleno, esto es, la totalidad de los miembros que componen el órgano, conociera de aquellos asuntos que tienen que ver con la constitucionalidad de la ley y con los problemas de la distribución competencial, y que las Salas cuya creación ya en su momento fue discutida, aunque resultó necesaria- se hicieran cargo, como una opción inevitable, del recurso de amparo. Lo que el proyecto ahora pretende es complicar ese esquema con la introducción de un tercer nivel de muy dudosa legitimidad, las Secciones, y enmarañar hasta el extremo la distribución de los distintos procesos entre los tres niveles de ahí resultantes, de manera que es muy difícil definir incluso qué pertenece a cada uno de ellos. Así, el control de constitucionalidad de la leyes ya no es sencillo saber si está encomendado al Pleno o a las Salas, porque si el conocimiento del asunto llega el al Tribunal Constitucional vía recurso la competencia es del Ple- 
no, pero éste puede deferirla a las Salas en los supuestos de mera aplicación de doctrina, y —a la inversa - si el asunto se plantea vía cuestión la competencia es de las Salas, pero siempre que el Pleno no la reclame para sí (lo que, por cierto, supone una infundada diferencia de régimen para el control sobre la ley según sea una u otra la vía por la que éste llegue al Tribunal). Algo semejante sucede con conflictos y con impugnaciones del 161.2, en los que la competencia es del Pleno, pero puede terminar en las Salas. Y, por lo que hace al amparo, la previsión del proyecto es que sean las Salas las que conozcan del mismo, pero, en el afán de sus autores de recurrir a la técnica de la descentralización incluso cuando ello no es compatible con las líneas maestras de la reforma (vid. respuesta núm. 3) ni resulta necesario (¿para qué necesitan las Salas descansar en otro nivel orgánico, si el certiorari permite al Tribunal controlar el número de amparos?), la reforma prevé que éstas puedan deferir su resolución a las Secciones.

Un verdadero embrollo, en suma, que despersonaliza los procesos al desconectarlos de un único órgano sentenciador, que resta con ello claridad y seguridad a nuestro modelo de justicia constitucional, que complica también la estructura del Tribunal al elevar a siete el número de órganos que pueden dictar sentencia, y que impide finalmente que el conocimiento de los asuntos más importantes (control de la ley, conflictos...) cuente a veces con la participación de la totalidad de los magistrados. Más aún, ese embrollo se causa además por el proyecto sin demasiado provecho, porque el órgano que defiere un asunto tendrá también que estudiarlo antes de tomar tal decisión; porque las Salas van a ver rota su especialización en amparos y van a tener que repartir su tiempo entre éstos y la cuestión de inconstitucionalidad; y, en la medida en que el proyecto no recorta la legitimación para recurrir, porque, tras ello, las demandas van a seguir llegando el Tribunal en un número preocupantemente alto.

\section{JESÚS GONZÁLEZ PÉREZ}

Podría contribuir a agilizar los procedimientos atribuir a las Salas competencias hasta ahora reservadas al pleno, aunque cuando la cuestión a resolver sea la inconstitucionalidad de una ley, creo que deben adoptar la decisión todos los miembros del Tribunal.

\section{PABLO LUCAS MURILLO DE LA CUEVA}

Es coherente con las otras medidas dirigidas a agilizar el trabajo del Tribunal Constitucional en el recurso de amparo y se prevé en términos prudentes. Obsérvese que la hace el Pleno en aquellos recursos y cuestiones de inconstitucionalidad en los que solamente se trate de aplicar una doctrina ya establecida, la cual, por lo demás, debe ser identificada por el propio Pleno en el mo- 
mento de la atribución. Y lo mismo debe decirse respecto de los conflictos y de las impugnaciones del artículo 161.2 de la Constitución aunque, respecto de ellos, el Proyecto de Ley Orgánica, debiendo hacerlo, no precise, en la nueva redacción del artículo 10.2 de la del Tribunal Constitucional que propone, que la Sala habrá de aplicar una determinada doctrina.

En tanto es cierto que bajo formas diferentes se replantean problemas ya afrontados y resueltos anteriormente y se suscitan otros que encuentran solución clara a partir de pronunciamientos precedentes, parece evidente que esta medida facilitará darles respuesta con los criterios ya sentados por la doctrina constitucional. De ahí que no deba ser problemático encomendar esta tarea a las Salas. Lo cual supondrá como consecuencia inmediata aligerar el trabajo del Pleno que así dispondrá de más tiempo para resolver aquellos procesos de inconstitucionalidad, conflictos o impugnaciones del artículo 161.2 del texto fundamental en los que se diluciden cuestiones nuevas o, aun versando sobre asuntos respecto de los que ya se ha manifestado el Tribunal Constitucional, por las circunstancias que en ellos concurran, considere que deben quedar bajo su conocimiento y decisión.

Así, pues, con la salvedad de que hace falta precisar, también en el caso de los conflictos y de las impugnaciones del artículo 161.2 de la Constitución, que la eventual remisión por el Pleno a las Salas de la decisión de fondo ha de hacerse indicando la doctrina a aplicar, me parece bien esta posibilidad.

ABSTRACT. The Organic Act of the Constitutional Court dated October the $3^{\text {rd }}$ 1979, wich has undergone five minor amendments, is now been reformed extensively in orden to deal with some operational problems. The Justices themselves had in several occasions set out such difficulties and insisted in the need of reform. The main point is to organize the appeal for protection (recurso de amparo), to wich the bulk of questions has been addressed. 